\title{
Heterogeneity in Intra-Monthly Consumption Patterns, Self-Control, and Savings at Retirement $\uplus^{\dagger}$
}

\author{
By Giovanni Mastrobuoni and Matthew WeinberG*
}

\begin{abstract}
Using data from the Continuing Survey of Food Intake by Individuals, this paper describes the shape of consumption profiles over the month for Social Security benefit recipients that have saved different amounts for retirement. Individuals with income mostly made up of Social Security and savings smooth consumption over the pay period, while individuals without savings consume 25 percent fewer calories the week before they receive checks relative to the week afterwards. The findings for individuals without savings, who comprise about a fourth of our sample, are inconsistent with the standard Life CyclePermanent Income Hypothesis but are consistent with hyperbolic discounting. (JEL D14, E21, J26)
\end{abstract}

M any economists and policymakers have questioned the adequacy of retirement savings for many US citizens. 1 One explanation for the low savings of some individuals is that they cannot resist the temptation of immediate gratification. ${ }^{2} \mathrm{~A}$ consumer with self-control problems indulges in high consumption today while promising herself that she will reduce her consumption and begin saving for retirement at a future date. Yet, when that future date arrives, she, again, caves in to the temptation of immediate gratification. Such individuals will reach an old age with little savings and, within a pay period, will have higher consumption immediately after receiving their pay.

In this paper, we provide evidence that elderly individuals with little savings suffer from self-control problems. We first provide a simple model of a dynamically inconsistent consumer who allocates consumption over the days of a pay period. This consumer does not have access to a commitment device. The model predicts consumption profiles will decline over the month at an increasing rate. We then use data from the Continuing

\footnotetext{
* Mastrobuoni: Collegio Carlo Alberto, Via Real Collegio 30, Moncalieri (TO) 10024, Italy and CeRP, Netspar (e-mail: giovanni.mastrobuoni@carloalberto.org); Weinberg: Department of Economics, Cornell University, Uris Hall, Ithaca, NY 14853 (e-mail: mw562@cornell.edu). We thank Orley Ashenfelter, Alessandro Barbarino, Giuseppe Bertola, Wioletta Dziuda, Adriaan Kalwij, Peter Katuscak, George Selgin, Jason Seligman, Karl Scholz, John Turner, two anonymous referees, and seminar participants at Collegio Carlo Alberto, the University of Georgia, the University of South Carolina, the 2007 meetings of the Western Economic Association, the workshop "Behavioral Approaches to Consumption, Credit, and Asset Allocation" of the Finance and Consumption Programme (European University Institute), and the Netspar Pension Workshop (University of Groningen) for suggestions. The views expressed are not necessarily those of the Federal Trade Commission.

${ }^{\dagger}$ To comment on this article in the online discussion forum, or to view additional materials, visit the articles page at http://www.aeaweb.org/articles.php?doi=10.1257/pol.1.2.163.

${ }^{1}$ For a survey of this literature, see Jonathan Skinner (2008).

${ }^{2}$ See David Laibson, Andrea Repetto, and Jeremy Tobacman (1998).
} 
Survey of Food Intake by Individuals (CSFII) to study differences in the shape of consumption profiles over the pay cycle for the elderly with different levels of savings.

We examine households containing an individual at least 62 years old who receives Social Security. While the CSFII does not contain information on pay dates, during the time period covered by our sample Social Security benefits are paid on the third of the month unless that day falls on a weekend or holiday ${ }_{3}^{3}$ We expect more power from our tests when households receive a large fraction of their income on one pay date, thus, we focus primarily on the 41 percent of our sample for whom Social Security income represents at least 80 percent of annual income ${ }^{4}$ The CSFII data allows us to study the difference in how consumption varies with time since checks were received between two groups: people with cash and savings above and below $\$ 5,000$. We refer to these groups as savers and nonsavers, respectively. Our model predicts that individuals who have reached this part of the life cycle with little savings will also have higher consumption at the beginning of the pay period, relative to the end of the pay period. Nonsavers behave like hyperbolic discounters, while savers smooth their consumption over the pay period.

Individuals with less than $\$ 5,000$ in savings have consumption that is 24 percent lower during the final few days of the pay cycle than it is during the first week. The people with little savings have consumption that decreases over the month even more dramatically when compared to the consumption of individuals with savings. Also, the rate of the decline in relative consumption of nonsavers is increasing over the Social Security payment cycle. Caloric intake falls by 11 percent more for nonsavers than savers over the first two weeks of the pay cycle, and by 35 percent more by the last three days of the pay cycle.

Not only do low savers consume less food at the end of the month, during this time they are also more likely to consume less than dietician prescribed amounts. We find that the likelihood of eating fewer calories than the prescribed recommended daily amount increases by 15 percent over the last ten days of the pay period.

The results in this paper complement the research of Erik Hurst (2003), who finds that households with food expenditures that are excessively sensitive to predictable income receipt also reach retirement with relatively little wealth in the Panel Study of Income Dynamics. This paper takes the reverse approach and finds that individuals who reach retirement age with little savings do not smooth their consumption over the pay cycle after that point in the life cycle. The research of Mark Aguiar and Hurst (2005) also finds evidence that part of the population with little wealth is not well described by the Permanent Income Hypothesis. Aguiar and Hurst's paper tests for a decline in food consumption and quality after retirement using CSFII data to highlight the distinction between expenditures and consumption. While the average household in the CSFII experiences no decline in the quantity or quality of food after retirement, households with less than $\$ 1,000$ of nonpension assets did experience a drop.

Our empirical results are somewhat surprising given the pioneering research of Melvin Stephens, Jr. (2003). Stephens' (2003) paper atheoretically tests for

\footnotetext{
${ }^{3}$ If the third day of the month falls on a weekend or holiday, benefits are paid on the first business day before the third.

${ }^{4}$ Our results are robust to this threshold.
} 
consumption smoothing among Social Security recipients. Using Consumer Expenditure Survey data, he tests for pay-date effects for Social Security recipients across a variety of expenditure categories. He finds large spikes in total expenditures on the pay date, but discounts the relevance of these spikes to testing the Life CyclePermanent Income Hypothesis because of the likely existence of lumpy, recurrent expenses that coincide with pay dates. Restricting his attention to narrower expenditure categories more likely to be consumed instantaneously, he finds much smaller pay-date effects. We avoid the difficulties in identifying goods for which expenditures track consumption, focus directly on actual measures of food consumption from the CSFII, and provide new evidence against consumption smoothing for a portion of our sample.

Our findings are difficult to explain using the standard Life Cycle-Permanent Income Hypothesis and exponential discounting. Robert E. Hall (1978) shows that exponential discounters with rational expectations, and the ability to transfer income from periods in which it is high to periods in which it is low, ought to have unpredictable changes in consumption around a linear trend. The elderly are, perhaps, the most likely individuals to satisfy Hall's assumptions, particularly when forming expectations is easy because their primary source of income is paid on predictable dates in predictable amounts. The elderly are experienced in budgeting and, because they do not have much future income they might like to transfer for current consumption, are unlikely to face credit constraints. For these reasons, we conclude from our empirical results that individuals with low savings have short-run impatience 5

The quasi-hyperbolic discounting model introduced by Edmund S. Phelps and Robert A. Pollak (1968) and expanded by Laibson $(1998,1997)$ provides a parsimonious framework for modelling short-run impatience. 6 Quasi-hyperbolic discounters discount the consumption between today and tomorrow at a higher rate than consumption between adjacent days further in the future, and this generates time inconsistency. In laboratory and field studies of time preferences, individuals (as well as animals) appear to have discount rates that decrease as the time horizon increases (George Ainslie 1992; Robert H. Thaler and George Lowenstein 1989). In their survey of the literature, Shane Frederick, Lowenstein, and Ted O'Donoghue (2002) provide evidence that long- and short-run discount rates differ, in general, with a meta-analysis of discount rate estimates across studies, where choices were made over different time-horizons. We simulate the quasi-hyperbolic discounting model to show that, unlike exponential discounting, it generates consumption profiles that decrease at an increasing rate over the pay cycle, which is similar to those actually observed for the group with low savings in our data.

A growing number of papers demonstrate that individuals suffer from self-control problems (Frederick, Lowenstein, and O'Donoghue 2002). Our paper contributes to this literature by linking behavior within the month to savings behavior over the entire life cycle, and by providing evidence that possibly not all individuals struggle with self-control equally in real-world markets. Jesse M. Shapiro (2005) uses

\footnotetext{
${ }^{5}$ An early formulation of dynamic inconsistency is Robert H. Strotz (1955).

${ }^{6}$ For an axiomatic model of temptation and self-control in which there is no dynamic inconsistency, see Faruk Gul and Wolfgang Pesendorfer (2001).
} 
the 1989-1991 CSFII data to study consumption profiles of food stamp recipients and concludes that their behavior is best reconciled with quasi-hyperbolic discounting. He does not consider heterogeneity though, probably because to be eligible for food stamps individuals need to be poor. Moreover, it is unclear whether his results are valid for those that are not stamp recipients. Our sample, in contrast, represents almost half of all elderly Social Security recipients, of which only about 8 percent receive food stamps. Further, by focusing on the behavior of individuals older than 62, we show that our model can explain the small accumulation of savings and high frequency, within the month consumption patterns! 7

\section{Intra-Monthly Consumption Profiles with Quasi-Hyperbolic Discounting}

In this section, we present a model of daily consumption decisions over a single month. On the first day of each pay period the consumer is given a fixed and certain amount of Social Security income, $y$, to finance their monthly food consumption over the discrete set of days $t=0, \ldots, T$. We assume Social Security is the only source of the consumer's income. Consumers set $y=\sum_{t=0}^{T} \quad c_{t}^{0}$.

Consumers maximize

$$
\max _{\left\{c_{t}^{0\}}\right.} u\left(c_{0}^{0}\right)+\beta \sum_{t=1}^{T} \delta^{t} u\left(c_{t}^{0}\right),
$$

where $\delta$ is the daily exponential discount factor, and $\beta$ is the quasi-hyperbolic discount factor. A consumer is quasi-hyperbolic if $\beta<1$, and, thus, has a discount rate between immediate consumption and consumption in the next period of $(1-\beta \delta) / \beta \delta$, and a smaller discount rate between consumption in any two future periods equal to $(1-\delta) / \delta$. We model consumption decisions over the short horizon of a pay period, so, we set $\delta=1$ and consider the case of $\delta<1$ in the Appendix.

Social Security checks are paid at perfectly predictable times and known amounts, which is why there is no uncertainty in our model. These checks are not reinvested. Since quasi-hyperbolic discounters make dynamically inconsistent choices, consumption profiles are superscripted. At time 0, the consumer " 0 " chooses a consumption profile $\left\{c_{t}^{0}\right\}_{t-1, \ldots, T}$ that is going to be different than the one he chooses a day later $\left\{c_{t}^{1}\right\}_{t=1, \ldots, T}$

The Euler equations are

$$
\begin{aligned}
& t=0: u^{\prime}\left(c_{0}^{0}\right)=\beta u^{\prime}\left(c_{1}^{0}\right)=\lambda, \\
& t>0: u^{\prime}\left(c_{t}^{0}\right)=u^{\prime}\left(c_{t+1}^{0}\right)=\lambda .
\end{aligned}
$$

\footnotetext{
${ }^{7}$ David Huffman and Matias Barenstein (2005) use UK Family Expenditure Survey data to show that expenditures decline between pay periods, and conclude this is largely due to costly decision making when budgeting.

${ }^{8}$ To derive closed form solutions, we assume that ex ante consumers do not realize the inconsistency of their behavior, they are "naïve." Our theoretical results do not depend on this assumption. If consumers are "sophisticated," meaning that they are aware of their time inconsistent behavior, the drop in consumption is the same as it is for "naïve" individuals if utility is logarithmic $(\rho=1)$, and is smaller (larger) for $\rho>1(\rho<1)$ (Pollak, 1968). In the case of $\rho>1$, as in the case with uncertainty, our estimated $\beta$ represents an upper bound on the true instantaneous discount factor.
} 
Assuming the felicity function $u(\cdot)$ is isoelastic, the Euler equations are

$$
\begin{gathered}
t=0: c_{1}^{0}=(\beta)^{1 / \rho} c_{0}^{0}, \\
t>0: c_{t}^{0}=c_{t-1}^{0}=c_{t-s}^{0}=\beta^{1 / \rho} c_{0}^{0} .
\end{gathered}
$$

In the Appendix, we show that log consumption chosen at time $t$ will be given by the expression

$$
\log c_{t}^{t}=\log y_{0}+\frac{t}{\rho} \log \beta+\sum_{s=0}^{t-1} \log (T-\mathrm{s}) \sum_{s=0}^{t} \log \left[1+\beta^{1 / \rho}(T-s)\right] .
$$

The decrease in log consumption over time is given by

$$
\frac{\partial \log c_{t}^{t}}{\partial t}=\frac{1}{\rho} \log \beta+\frac{-1}{T-t+1}+\frac{1}{T-t+\beta^{-1 / \rho}}<0,
$$

and it is easy to verify that the consumption profile is concave if $\beta<1$. Consumption becomes constant over the month as $\beta$ approaches one.

Figure 1 plots log consumption over the pay period for a yearly discount factor of 0.97 and different values of $\beta$. Log consumption has been normalized to zero at time zero in order to ease the interpretation of the empirical results that are shown later. The benchmark exponential discounters $(\beta=1)$ have consumption that is flat over the pay period if $\delta=1$, and for smaller values of $\delta$, have a decline that follows a straight line with a slope of $\log (\delta) / \rho$, where $\rho$ is the inverse of the intertemporal elasticity of substitution.

A 20 percent drop in consumption over the pay period can be explained by any combination of $\rho$ and $\delta$ that satisfies the equation $-0.20=30 \log (\delta) / \rho$. If the consumer was not hyperbolic, she would have to be extremely impatient to explain a 20 percent drop in consumption over a month. Specifically, the implied yearly discount factor, $[\exp (-0.2 \rho / 30)],{ }^{365}$ would be 0.08 if $\rho=1$, and basically zero if $\rho=4$. Further, an extremely impatient exponential discounter would have log consumption that declines at a constant rate, whereas exponential discounters have consumption that declines at an increasing rate.

In our model, we assumed that consumers do not borrow against future income. A few comments are in order to justify this assumption. Though it is actually illegal to borrow against Social Security income, some retired Social Security benefits recipients might be able to use credit cards to finance current consumption with future income. However, several studies suggest that by the age of retirement a hyperbolic discounter would have extremely bad credit, thus making this option very expensive if possible. Laibson, Repetto, and Tobacman (2003) simulate that a hyperbolic discounter will hold over three times as much debt as an exponential discounter even when faced with a higher interest rate. Because hyperbolic discounters procrastinate in paying off their debt, they are prone to bad credit and financial distress (Michelle J. White 2007). 


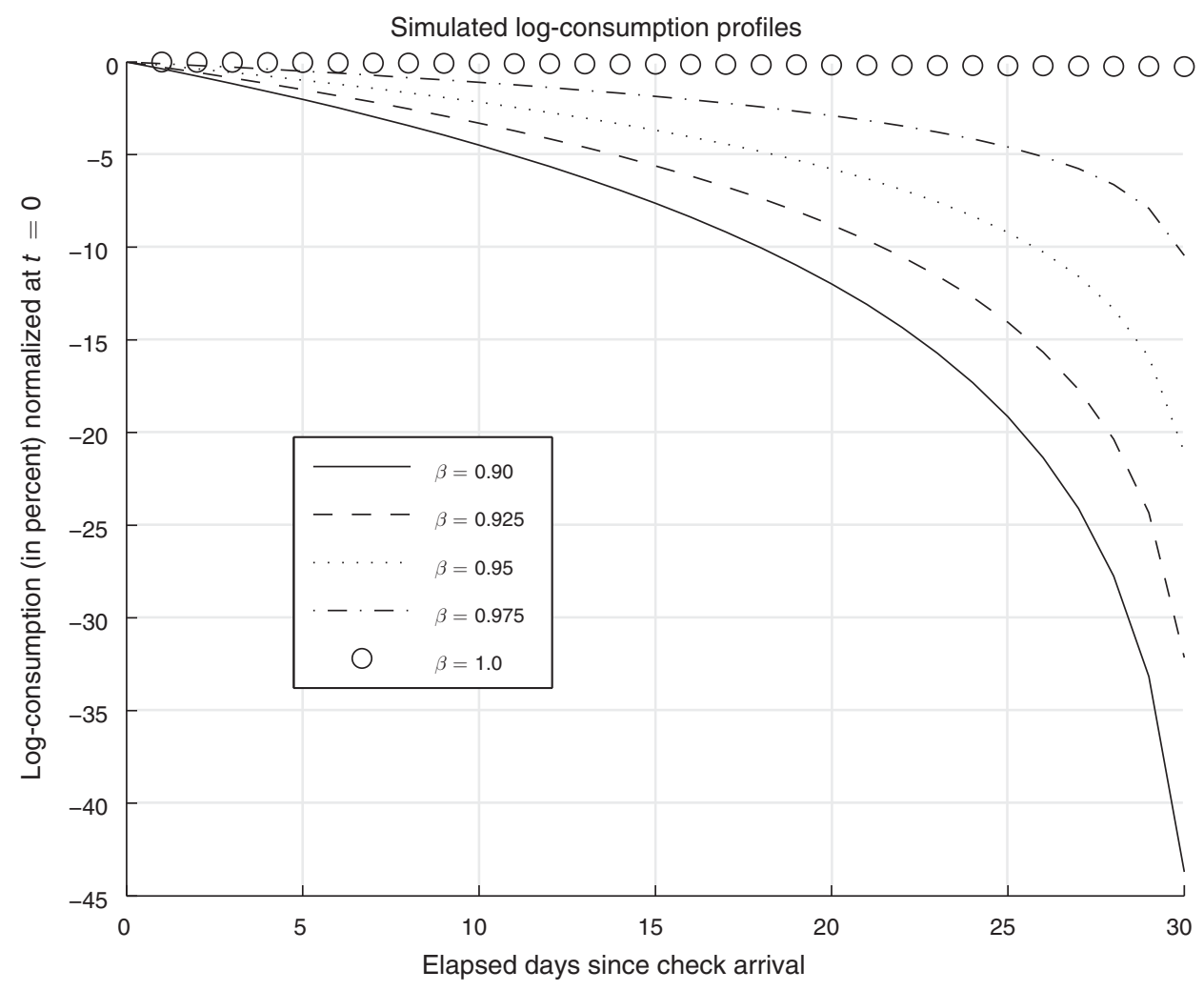

Figure 1. Monthly Consumption Pattern: $\delta=0.97 ; \rho=1$

\section{Data and Sample Restrictions}

We are interested in the shape of consumption profiles over the pay period. We follow Aguiar and Hurst (2005), and Shapiro (2005) and focus on food consumption (primarily caloric intake) to avoid measurement issues associated with using expenditure data to test models of consumption. This is appropriate if food consumption is separable from other forms of consumption. For support of this assumption, see Emily C. Lawrance (1991).

We use data from the Continuing Survey of Food Intake by Individuals, 1994-1996 to explore the consumption behavior of households containing individuals that receive Social Security benefits and a member older than 62 years old. The CSFII is randomly administered by the US Department of Agriculture (USDA) to individuals over the month. During the time period covered by our data, Social Security benefits were paid out on the third of the month if that date was neither a holiday nor on the weekend, and, otherwise, on the first day prior to the third of the month that was not a holiday or on the weekend. Between 1994 and 1996, on average, 60 percent of Social Security recipients received their checks via direct deposit and would, therefore have access to their benefits on pay dates (Social Security Administration (SSA) 
1989-1996) ${ }^{9}$ The exogenous variation in interview date and knowledge of pay dates allows us to identify the effect of time elapsed since checks were received on consumption. Survey respondents were asked to recall everything they ate over the last 24 hours, and the USDA implemented procedures and prompts developed by the US Census Bureau's Center for Survey Methods Research that would improve response accuracy (USDA 1997). Households were to be interviewed a second time between three and ten days after initially being interviewed. The attrition rate between the first and second interview is 10 percent, and 22 percent of second interview dates actually occurred outside the planned window of between 3 and 10 days after the initial interview in the CSFII, 1994-1996. For these reasons, we use only the initial interviews. 10 We also exclude individuals who did not know if they were receiving Social Security benefits. The overall response rate for the first interview was 80 percent.

The CSFII data contain observations on 12,364 households of which 2,332 receive Social Security benefits. This yields 3,600 first-day surveys. ${ }^{11}$ We expect more power from our tests when households receive a large fraction of their income on the third of the month. For that reason, we focus on individuals from households in which Social Security income makes up at least 80 percent of total income, and these individuals make up 41 percent of our sample. We estimate consumption profiles over the pay cycle separately for two groups of households that we call savers and nonsavers. While the CSFII does not contain information on the exact amount of savings held by each household, it does contain the question "Consider cash, savings or accounts, stocks, bonds, mutual funds, and certificates of deposit. Do the members of this household have more than $\$ 5,000$ of savings or cash assets at this time?" We classify households as savers if they answer "yes" to this question and as nonsavers otherwise. Fifty-four percent of our final sample has cash and savings below $\$ 5,000$. Eighty-five percent of these households have savings below $\$ 500$, and another 9 percent have savings between $\$ 501$ and $\$ 1,000$. Only 5 percent of households have between $\$ 2,000$ and $\$ 5,000$ in savings. We have no information about the amount of savings by households that declare to have more than $\$ 5,000$ in liquid assets.

We identify the shape of consumption profiles over the month under the assumption of random assignment of CSFII interview date to each household. This generates exogenous variation in the duration since paychecks were received. To test that the interview date is exogenous, various factors that determine consumption were regressed on dummies $D 2-D 5$, indicating if interviews occurred two, three, four, or five weeks after pay was received. We test for differences in weeks in the pay period separately for typical monthly food expenditures, Social Security benefits, age, years of education, and indicators for whether a household is located in the Midwest, South, or West. We also test for differences in indicators for whether the survey respondent is in good health, has poor health, and is male, black, retired, or

\footnotetext{
${ }^{9}$ Between 1989 and 1992, only 51.5 percent of recipients used direct deposit, which makes the CSFII, 19891992 less appropriate for our analysis because our approach depends on the exact knowledge of the pay date.

${ }^{10}$ Given the detailed nature of these surveys, survey fatigue may be an issue as well. Our results are qualitatively similar, though somewhat dampened when both interview dates are used.

${ }^{11}$ There are more first-day surveys than households that receive Social Security because of multi-person households.
} 
TABLE 1-Test For RANDomization of InTERView Dates

\begin{tabular}{|c|c|c|c|c|c|c|c|}
\hline & $\begin{array}{c}\log \\
\text { food } \\
\text { expend. } \\
(1)\end{array}$ & $\begin{array}{c}\log \\
\text { benefits } \\
\text { (2) }\end{array}$ & $\begin{array}{c}\text { Dummy } \\
\text { MW } \\
\text { (3) }\end{array}$ & $\begin{array}{c}\text { Dummy } \\
\text { SO } \\
(4)\end{array}$ & $\begin{array}{c}\text { Dummy } \\
\text { WE } \\
(5)\end{array}$ & $\begin{array}{l}\text { Dummy } \\
\text { good } \\
\text { health } \\
(6)\end{array}$ & $\begin{array}{c}\text { Dummy } \\
\text { poor } \\
\text { health } \\
(7)\end{array}$ \\
\hline \multicolumn{8}{|c|}{ Panel A. Savers } \\
\hline$F$-stat & 1.03 & 0.77 & 1.16 & 1.89 & 0.70 & 1.37 & 3.30 \\
\hline$p$-value & 0.40 & 0.55 & 0.34 & 0.12 & 0.59 & 0.25 & 0.02 \\
\hline$R^{2}$ & 0.02 & 0.03 & 0.03 & 0.03 & 0.02 & 0.01 & 0.01 \\
\hline Observations & 346 & 346 & 346 & 346 & 346 & 346 & 346 \\
\hline \multicolumn{8}{|c|}{ Panel B. Nonsavers } \\
\hline$F$-stat & 1.84 & 1.18 & 2.15 & 2.60 & 2.73 & 0.45 & 0.18 \\
\hline$p$-value & 0.13 & 0.33 & 0.08 & 0.04 & 0.04 & 0.77 & 0.95 \\
\hline$R^{2}$ & 0.02 & 0.02 & 0.04 & 0.03 & 0.01 & 0.01 & 0.00 \\
\hline Observations & 399 & 399 & 399 & 399 & 399 & 399 & 399 \\
\hline \multicolumn{8}{|c|}{ Panel C. Savers and nonsavers joint test } \\
\hline$F$-stat & 2.34 & 1.30 & 1.62 & 2.22 & 1.38 & 0.85 & 1.68 \\
\hline$p$-value & 0.03 & 0.26 & 0.13 & 0.04 & 0.22 & 0.56 & 0.12 \\
\hline$R^{2}$ & 0.07 & 0.16 & 0.06 & 0.04 & 0.02 & 0.02 & 0.03 \\
\hline Observations & 745 & 745 & 745 & 745 & 745 & 745 & 745 \\
\hline
\end{tabular}

Notes: F-stats correspond to tests of the joint null that coefficients on the four week dummies are each zero. Panels $\mathrm{A}$ and $\mathrm{B}$ test for savers and nonsavers, respectively, while panel $\mathrm{C}$ presents joint tests. Regressions estimated on CSFII data restricted to households with individuals older than 62 obtaining Social Security income that is at least 80 percent of total income. Savings is defined as having cash, savings or checking accounts, stocks, bonds, mutual funds and certificates of deposit worth at least $\$ 5,000$.

receives food stamps. Table 1 presents $F$-tests of the null hypothesis that each of the coefficients on the week dummies are equal to zero, separately for savers and nonsavers. Panel C presents joint tests for the week dummies and their interaction with dummies indicating if the household is a saver. Under the null of randomization, we would expect no differences in any of the variables across weeks of the pay period.

We reject the test that the week dummies are jointly zero at the 5 percent level for the regional dummies indicating if the household is located in the South or the West and the dummy indicating the household receives food stamps. Food stamp recipients and individuals living in the South were more likely to be interviewed at the beginning of the pay cycle. One possible explanation is that the survey was administered at different times for each region. In our regressions, we control for these variables. To the extent that consumption is lower for households living in the South and on food stamps due to unobservables, their prevalence in the beginning of the month will bias our results against finding a decline in consumption over the pay cycle. Further, only 16 percent of the nonsavers receive food stamps, and all of our results are robust to excluding these households from the analysis.

Table 2 presents descriptive statistics for savers and nonsavers. These two groups are very different from each other. Savers have higher benefits than nonsavers, which implies that savers had higher labor earnings over their careers. Savers are also more likely to be in good health, male, white, and have, on average, two more years of education than nonsavers. 
Table 1-Test for Randomization of Interview Dates (Continued)

\begin{tabular}{|c|c|c|c|c|c|c|c|c|}
\hline & $\begin{array}{c}\text { Age } \\
(8)\end{array}$ & $\begin{array}{c}\text { Dummy } \\
\text { male } \\
(9)\end{array}$ & $\begin{array}{c}\text { Dummy } \\
\text { black } \\
(10)\end{array}$ & $\begin{array}{l}\text { Years of } \\
\text { education } \\
\text { (11) }\end{array}$ & $\begin{array}{c}\text { Dummy } \\
\text { retired } \\
(12)\end{array}$ & $\begin{array}{c}\text { Dummy } \\
\text { food } \\
\text { stamps } \\
(13)\end{array}$ & $\begin{array}{c}\text { HH size } \\
(14)\end{array}$ & $\begin{array}{c}\text { Height } \\
(15)\end{array}$ \\
\hline \multicolumn{9}{|c|}{ Panel A. Savers } \\
\hline$F$-stat & 1.54 & 0.76 & 1.55 & 0.47 & 0.54 & 0.98 & 1.43 & 1.09 \\
\hline$p$-value & 0.20 & 0.56 & 0.21 & 0.76 & 0.70 & 0.33 & 0.23 & 0.37 \\
\hline$R^{2}$ & 0.02 & 0.00 & 0.01 & 0.00 & 0.01 & 0.01 & 0.02 & 0.01 \\
\hline Observations & 346 & 346 & 346 & 346 & 346 & 346 & 346 & 346 \\
\hline \multicolumn{9}{|c|}{ Panel B. Nonsavers } \\
\hline$F$-stat & 0.90 & 0.64 & 0.89 & 1.50 & 0.53 & 5.70 & 1.17 & 0.86 \\
\hline$p$-value & 0.47 & 0.64 & 0.48 & 0.21 & 0.71 & 0.00 & 0.33 & 0.49 \\
\hline$R^{2}$ & 0.01 & 0.00 & 0.02 & 0.02 & 0.01 & 0.03 & 0.01 & 0.01 \\
\hline Observations & 399 & 399 & 399 & 399 & 399 & 399 & 399 & 399 \\
\hline \multicolumn{9}{|c|}{ Panel C. Savers and nonsavers joint test } \\
\hline$F$-stat & 1.07 & 0.80 & 1.10 & 1.13 & 0.71 & 4.79 & 1.43 & 1.20 \\
\hline$p$-value & 0.39 & 0.61 & 0.37 & 0.35 & 0.68 & 0.00 & 0.20 & 0.31 \\
\hline$R^{2}$ & 0.03 & 0.03 & 0.10 & 0.12 & 0.01 & 0.12 & 0.02 & 0.02 \\
\hline Observations & 745 & 745 & 745 & 745 & 745 & 745 & 745 & 745 \\
\hline
\end{tabular}

Notes: $F$-stats correspond to tests of the joint null that coefficients on the four week dummies are each zero. Panels $\mathrm{A}$ and $\mathrm{B}$ test for savers and nonsavers, respectively, while panel $\mathrm{C}$ presents joint tests. Regressions estimated on CSFII data restricted to households with individuals older than 62 obtaining Social Security income that is at least 80 percent of total income. Savings is defined as having cash, savings or checking accounts, stocks, bonds, mutual funds and certificates of deposit worth at least $\$ 5,000$.

\section{Consumption over the Pay-Cycle}

\section{A. Graphical Evidence}

Figure 2 presents $\log$ consumption (times 100) averaged over three-day and sevenday intervals across the pay cycle for respondents whose Social Security income comprised at least 80 percent of total income. The dashed lines are for nonsavers and the dashed/dotted lines are for savers. Ninety percent confidence bands are included. The nonsavers consumption decreases over the last ten days of the pay period, while the savers consumption remains basically constant in the three-day graph. All results are qualitatively similar when the sample is broadened to include households with Social Security income representing at least 70 percent of total income, and we show the robustness of our conclusion to income threshold in Section IIIC. We, pext, estimate local linear regressions in order to eliminate the kinks in the graphs $\stackrel{12}{ }$ While the graphical evidence conveys the main results of this paper, we use regression to test if the decline in consumption is statistically significant in Section IVB.

The local linear regressions are displayed in Figure 3. The apparent randomization of interview date over the pay cycle obviates the need to control for determinants of

\footnotetext{
${ }^{12}$ See William S. Cleveland (1979).
} 
Savers (transparent $\mathrm{Cl}$ ) and nonsavers (shaded $\mathrm{Cl}$ )

Log consumption over the pay period
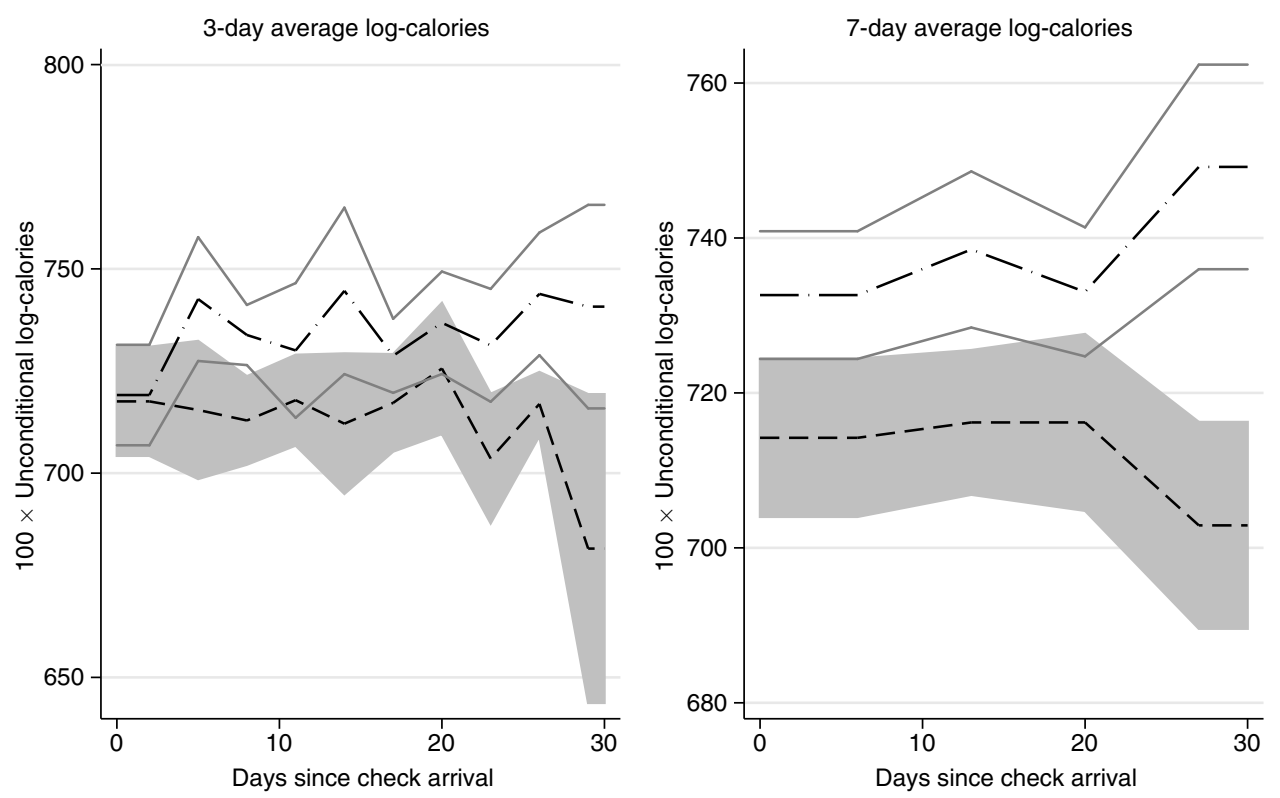

Figure 2. Log CONSUMPTION

Note: Figures are average consumption by 3 - and 7-day intervals over the pay period with 90 percent confidence bands.

consumption when estimating the shape of consumption over the pay cycle. However, there is a great deal of variation in caloric intake across individuals, and adjusting for these factors will increase the precision of our estimates. For that reason, we adjust the graph by plotting the component of log consumption orthogonal to factors that determine the level of consumption. These factors include usual monthly food expenditures, gender, household size, age, an age-gender interaction, self-reported health indicators, highest year of schooling completed (with a dummy variable for missing values), height, race, retirement status, a dummy indicating whether the respondent receives food stamps, and additional dummy variables indicating survey year, month, and day of week, region, typical shopping frequency, and MSA status. The dashed curves are for individuals with assets valued at less than $\$ 5,000$, and the dash/dot curves are for individuals with assets of value greater than $\$ 5,000$. Ninety percent confidence bands were constructed by block boostrapping across survey stratum. Throughout, we use the CSFII provided survey weights to insure our sample is representative of the US population.

Figure 3 demonstrates that the consumption of households with higher valued liquid assets is fairly flat. In contrast, caloric intake for those with little savings is decreasing. Initially, caloric intake is roughly the same for low-savings individuals as it is for high-savings individuals, though this changes not long after they receive benefits. Caloric intake drops dramatically for low-savings individuals during the last five days of the pay cycle. For nonsavers, caloric intake is almost 20 percent 
Savers (transparent $\mathrm{Cl}$ ) and nonsavers (shaded $\mathrm{Cl}$ )

Unconditional log consumption over the pay period
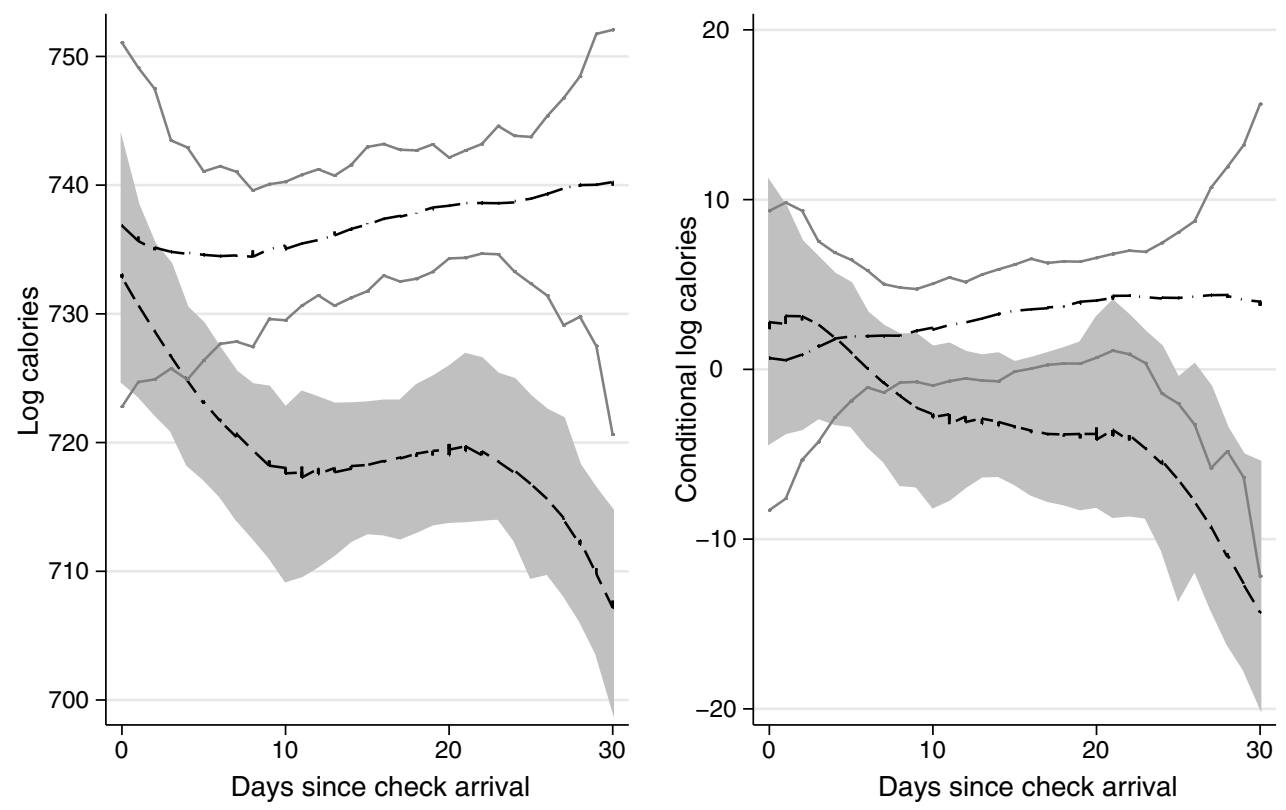

Figure 3. Log CONSUMPTION

Notes: Figures are locally weighted regression plots of weighted daily average $100 \times \log$ consumption and weighted daily average adjusted log consumption for households with benefits that are at least 80 percent of total income. In the second panel, log consumption is adjusted for "usual monthly food expenditures," gender, household size, age, age-gender interactions, self-reported health indicators, highest year of schooling, height, race, retirement status, and food stamp recipient, month, year, day of week, region, typical shopping frequency, and MSA status dummies. Ninety percent confidence intervals are constructed by block bootstrapping by survey stratum.

lower than average 30 days after pay is received. A comparison of this pattern with the simulated patterns in Figure 1, reveals that assuming an intertemporal rate of substitution of 1 and a yearly discount rate of 0.03 implies that the instantaneous discount factor $\beta$ is close to 0.95 . Reducing the intertemporal rate of substitution to one-fourth, so that a 10 percent rise in relative prices causes a 2 percent reduction in relative consumption, gives $\beta=0.8$.

Total caloric intake falls over the pay cycle for individuals with little savings. This alone does not prove that consumers are failing to smooth their marginal utility of consumption if the content of diets changes over the pay cycle. Next, we explore how the content of the typical diet for savers and nonsavers changes over the pay cycle. Figure 4 contains locally weighted regression plots of the incidence of eating out and other consumption quality measures, conditional on the log of total calories and the same controls used to construct Figure 3.

Aguiar and Hurst (2005) estimate an income elasticity of the incidence of eating out of the household of 0.16 for a sample of household heads age 45-55 years old and conclude that part of the luxury nature of meals eaten out of the house is due to their higher quality. The first panel of Figure 4 shows how the probability of eating 
Table 2-Descriptive Statistics for Households With SaVings ABOVE AND BELOW \$5,000

\begin{tabular}{|c|c|c|c|}
\hline & Nonsavers & Savers & Difference \\
\hline Food expenditures & $\begin{array}{c}233.120 \\
(12.149)\end{array}$ & $\begin{array}{l}347.557 \\
(28.850)\end{array}$ & $\begin{array}{r}-114.437 \\
(26.586)\end{array}$ \\
\hline Social Security benefits & $\begin{array}{l}772.938 \\
(26.335)\end{array}$ & $\begin{array}{r}1,181.711 \\
(57.516)\end{array}$ & $\begin{array}{r}-408.773 \\
(61.313)\end{array}$ \\
\hline Mid-West & $\begin{array}{c}0.220 \\
(0.083)\end{array}$ & $\begin{array}{c}0.378 \\
(0.116)\end{array}$ & $\begin{array}{r}-0.158 \\
(0.066)\end{array}$ \\
\hline South & $\begin{array}{c}0.401 \\
(0.104)\end{array}$ & $\begin{array}{c}0.283 \\
(0.091)\end{array}$ & $\begin{array}{c}0.118 \\
(0.048)\end{array}$ \\
\hline West & $\begin{array}{c}0.112 \\
(0.044)\end{array}$ & $\begin{array}{c}0.142 \\
(0.066)\end{array}$ & $\begin{array}{r}-0.030 \\
(0.040)\end{array}$ \\
\hline Rural & $\begin{array}{c}0.309 \\
(0.106)\end{array}$ & $\begin{array}{r}0.347 \\
(0.116)\end{array}$ & $\begin{array}{r}-0.038 \\
(0.059)\end{array}$ \\
\hline Good health & $\begin{array}{c}0.284 \\
(0.023)\end{array}$ & $\begin{array}{c}0.390 \\
(0.025)\end{array}$ & $\begin{array}{r}-0.105 \\
(0.031)\end{array}$ \\
\hline Poor health & $\begin{array}{c}0.128 \\
(0.022)\end{array}$ & $\begin{array}{c}0.042 \\
(0.012)\end{array}$ & $\begin{array}{c}0.087 \\
(0.025)\end{array}$ \\
\hline Age & $\begin{array}{l}73.090 \\
(0.507)\end{array}$ & $\begin{array}{l}74.738 \\
(0.431)\end{array}$ & $\begin{array}{r}-1.648 \\
(0.719)\end{array}$ \\
\hline Male & $\begin{array}{c}0.273 \\
(0.023)\end{array}$ & $\begin{array}{c}0.418 \\
(0.021)\end{array}$ & $\begin{array}{r}-0.145 \\
(0.034)\end{array}$ \\
\hline Black & $\begin{array}{c}0.204 \\
(0.035)\end{array}$ & $\begin{array}{r}0.020 \\
(0.013)\end{array}$ & $\begin{array}{c}0.185 \\
(0.033)\end{array}$ \\
\hline Years of education & $\begin{array}{c}9.117 \\
(0.236)\end{array}$ & $\begin{array}{l}11.539 \\
(0.280)\end{array}$ & $\begin{array}{r}-2.422 \\
(0.320)\end{array}$ \\
\hline Fraction retired & $\begin{array}{c}0.757 \\
(0.031)\end{array}$ & $\begin{array}{c}0.773 \\
(0.030)\end{array}$ & $\begin{array}{r}-0.016 \\
(0.040)\end{array}$ \\
\hline Food stamps & $\begin{array}{c}0.172 \\
(0.024)\end{array}$ & $\begin{array}{c}0.003 \\
(0.003)\end{array}$ & $\begin{array}{c}0.169 \\
(0.024)\end{array}$ \\
\hline Household size & $\begin{array}{c}1.675 \\
(0.072)\end{array}$ & $\begin{array}{c}1.750 \\
(0.060)\end{array}$ & $\begin{array}{r}-0.076 \\
(0.089)\end{array}$ \\
\hline Height (inches) & $\begin{array}{c}65.068 \\
(0.328)\end{array}$ & $\begin{array}{c}65.997 \\
(0.278)\end{array}$ & $\begin{array}{r}-0.929 \\
(0.419)\end{array}$ \\
\hline Observations & 399 & 346 & \\
\hline
\end{tabular}

Notes: CSFII data is restricted to households older than 62 obtaining Social Security income that is at least 80 percent of total income. Savings is defined as having cash, savings or checking accounts, stocks, bonds, mutual funds and certificates of deposit worth at least $\$ 5,000$. Standard errors, along with sample size, are reported instead of standard deviations.

a meal out of the household changes over the pay cycle. While the incidence of dining at a restaurant is nearly equal at the beginning of the pay period for savers and nonsavers, the gap widens substantially over the month. The likelihood of eating out falls by about 15 percent for nonsavers by the end of the month.

Next, we construct a quality index of food consumption in dollar terms. This is done by first running the regression:

$$
\log \left(\text { Income }_{i}\right)=\sum_{j=1}^{K} \alpha_{j} \log c_{i}^{j}+\mathbf{X}_{i}^{\prime} \boldsymbol{\beta}+\varepsilon_{i},
$$




\section{Savers (transparent $\mathrm{Cl}$ ) and nonsavers (shaded $\mathrm{Cl}$ )}

Conditional log consumption over the pay period
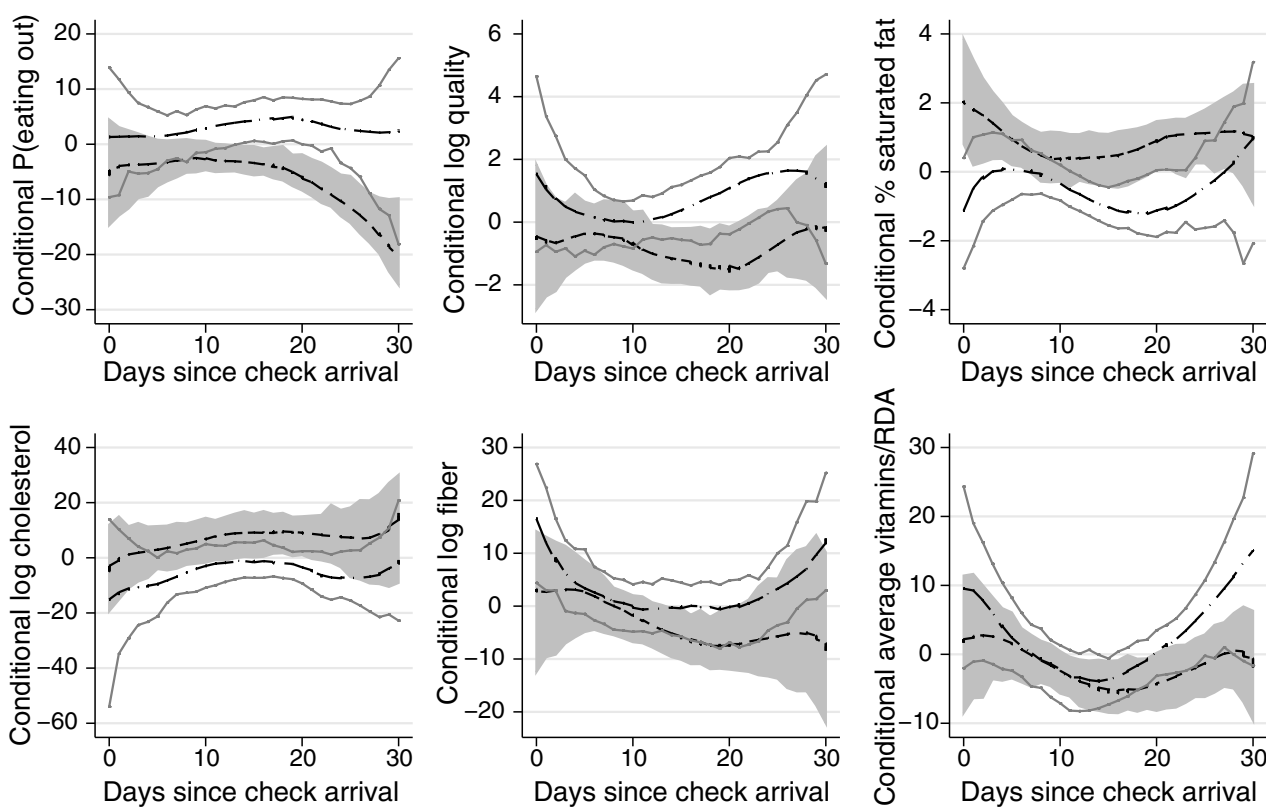

Figure 4. Log CONSUMPTION

Notes: Figures are locally weighted regression plots of daily average adjusted log consumption over the Social Security pay cycle for households with benefits that are at least 80 percent of total income where total log calories are controlled for along with determinants of consumption described in text. Log consumption is adjusted for "usual monthly food expenditures," gender, household size, age, age-gender interactions, self-reported health indicators, highest year of schooling, height, race, retirement status, and food stamp recipient, month, year, day of week, region, typical shopping frequency, and MSA status dummies. Ninety percent confidence intervals are constructed by block bootstrapping by survey stratum.

where the $K$ consumption components $c^{j}$ include log-saturated fat $(\beta=-0.15$; s.e. $=0.04)$, log-unsaturated fat $(\beta=0.15$; s.e. $=0.04)$, log-cholesterol $(\beta=-0.05$; s.e. $=0.03)$, log-carbohydrates $(\beta=0.09$; s.e. $=0.04)$, log-proteins $(\beta=0.10$; s.e. $=0.05)$, and log-vitamins $\mathrm{A}(\beta=0.00$; s.e. $=0.01)$, B12 $(\beta=0.02$; s.e. $=0.02)$, and $\mathrm{C}(\beta=0.04$; s.e. $=0.01)$. The $\mathbf{X}$ vector contains the same controls as before, with the exception of usual expenditures. We estimate this equation using OLS on all household heads at least 50 years of age. We then use the estimates $\hat{\alpha}_{j}$ to construct the quality index

$$
\text { Quality }_{i}=\sum_{j=1}^{K} \hat{\alpha}_{j} \log c_{i}^{j} .
$$

Because, here, we are interested in the content of a diet and not the size consumption, we regress log quality on total calories along with our demographic controls. The locally weighted smoothed scatter plot of adjusted consumption is in the second panel of Figure 4. The third panel of Figure 4 contains the fraction of fat that is saturated (not conditional on calories). The fourth and fifth panels contain log cholesterol 
and $\log$ fiber (conditional on calories), and the sixth (final) panel of Figure 4 contains the average intake of vitamin A, E, C, B6, B12, thiamin, riboflavin, and niacin as a percentage of their recommended daily amounts (conditional on calories). Though the confidence bands are fairly wide, the figures imply nonsavers diets contain slightly more fat and cholesterol toward the end of the pay period. The quality index is not changing over the pay period.

The sudden drop in food consumption for the elderly without savings also has implications for health. Dieticians are concerned that a large number of elderly individuals are at nutritional risk. For example, Jon P. Weimer (1997) reports that, for men age 60 or older, caloric intake is, on average, only 80 percent of the Recommended Daily Amounts (RDA) issued by the National Academy of Sciences and only 73 percent of the RDA for women in the CSFII. Further, the average caloric intake for people 60 years old or older is 1,953 for men and 1,488 for women in the CSFII. In the National Health and Nutrition Examination Survey, 1989-1991, the average caloric intake is 1,956 for men and 1,454 for women.

Figure 5 contains plots of the probability of consuming less than the USDA recommended consumption level for total calories. In our sample, during the first week of the pay period, over 80 percent of respondents do not meet their RDA, and the likelihood of eating fewer calories than the prescribed Recommended Daily Amount increases by 15 percent over the last ten days of the pay period for non savers.

\section{B. Regression Estimates}

In this section, we estimate the simple model of intra-monthly consumption decisions presented in Section II. We then employ regression to conduct inference and further explore the path of consumption over the pay cycle described graphically in Section IIIA.

Equation (3) gives daily consumption for a hyperbolic discounter. Assuming logarithmic utility $(\rho=1), \log$ consumption $\log c_{i}$ of household $i$ observed $t_{i}$ days after pay was received is given by

(3) $\log c_{i}=\log y_{i 0}+\frac{t_{i}}{1} \log \beta+\log \left(T ! /\left(T-t_{i}\right) !\right)-\sum_{s=0}^{t_{i}} \log [1+\beta(T-s)]+\varepsilon_{i}$,

where $\varepsilon_{i}$ represents an idiosyncratic shock 13 We estimate this equation with nonlinear least squares separately for savers and nonsavers, and test the null of having no short-run impatience $(\beta=1)$ for each group. Differences in the level of consumption, that depend only on income in the model, are allowed to vary with the same demographics used to produce the graphs as well 14 Therefore, identification of $\beta$ is only based on the evolution of log-consumption over the pay period. Columns 1 and 4 of Table 4 show estimates of $1-\beta$. Nonsavers have $\beta$ estimated at 0.94 and

\footnotetext{
${ }^{13}$ A normalization of $\rho$ is needed as $\beta$ and $\rho$ are not separately identified otherwise.

${ }^{14}$ We include usual food expenditure, gender, household size, age, an age-gender interaction, health indicators, highest year of schooling completed (with a dummy variable for missing values), height, race, retirement status, a dummy indicating whether the respondent receives food stamps, and additional dummy variables indicating month, year, day of the week, region, shopping frequency, and MSA status.
} 
Savers (transparent $\mathrm{Cl}$ ) and nonsavers (shaded $\mathrm{Cl}$ ) savings

Unconditional probability over the pay period
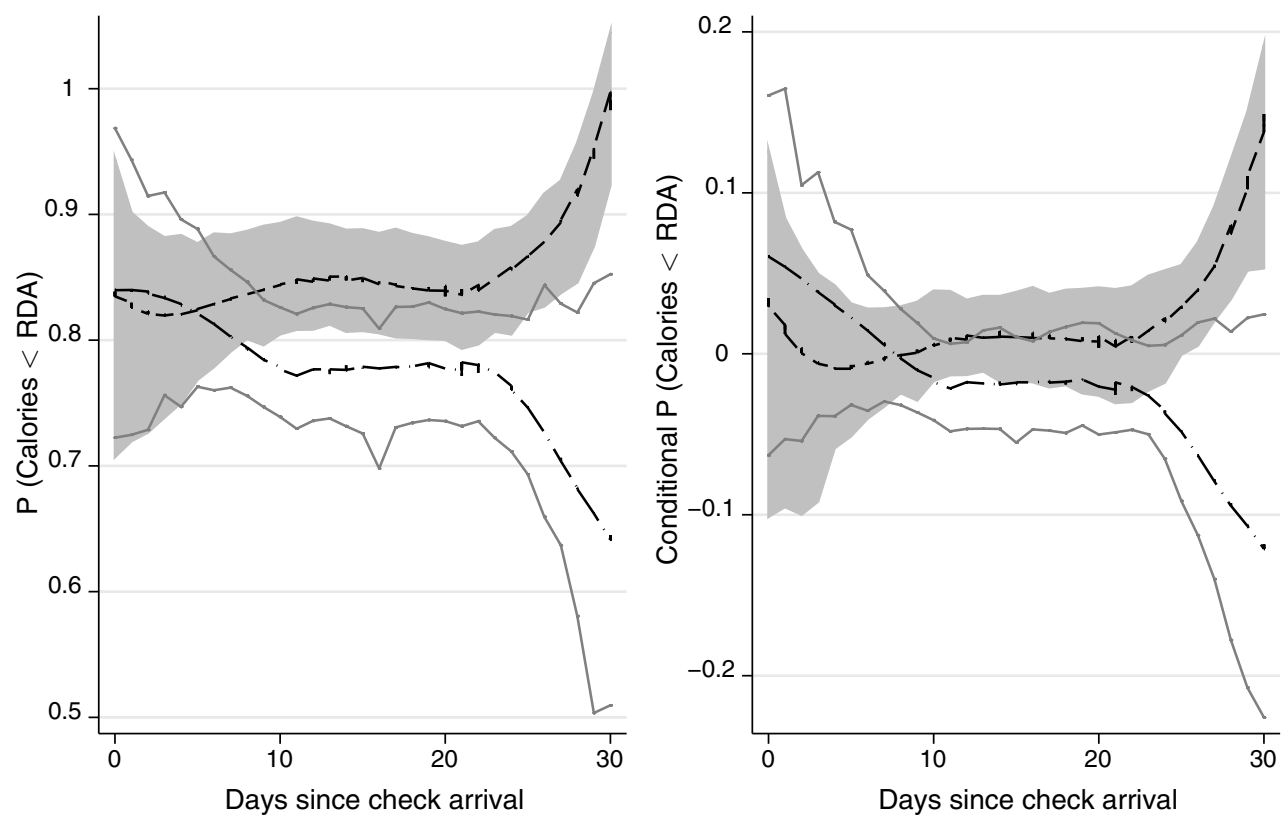

Figure 5. Probability of Eating Less than RDA over the Pay Period

Notes: These figures are locally weighted regression plots of the probability of consumping calories less than recommended daily amount over the Social Security pay cycle for households with benefits that are at least 80 percent of total income. In the second panel, log consumption is adjusted for "usual monthly food expenditures," gender, household size, age, age-gender interactions, self-reported health indicators, highest year of schooling, height, race, retirement status, and food stamp recipient, month, year, day of week, region, typical shopping frequency, and MSA status dummies. Ninety percent confidence intervals are constructed by block bootstrapping by survey stratum.

significantly different from one at the 0.05 level. Savers, instead, show a discount factor that is statistically indistinguishable from one at conventional levels.

Columns 2 and 5 present estimates of the exponential discounting model. In this model, the evolution of log consumption is linear, with slope equal to the log of the daily exponential discount factor: 15

$$
\log c_{i}=\log y_{i 0}+t_{i} \log (\delta)+\log \left(\frac{1-\delta}{1-\delta^{(T+1) / \rho}}\right)+\varepsilon_{i}
$$

We estimate $\log (\delta)$ and use the delta method to approximate the standard error of $\hat{\delta}$, again controlling for demographics. The estimated $\delta$ is 99.5 percent for nonsavers and is significantly different from one. For savers the estimate is not significantly different from 1 .

\footnotetext{
${ }^{15}$ The derivation of the optimal consumption path in this model holds for $\delta$ less than, but arbitrarily close to, one. See the Appendix for further detail.
} 
In columns 3 and 6 , we jointly estimate the exponential and the hyperbolic model. This allows us to test our hyperbolic discounting model, $\beta<1$ and $\delta=1$, against the exponential discounting model, $\delta \leq 1$ and $\beta=1$. For nonsavers, we reject the exponential model and accept the hyperbolic one, that is, $\beta$ is significantly lower than one, while $\delta$ is not. For savers, instead, none of the coefficients are significantly different than one, which indicates perfect consumption smoothing.

Next, we run regressions of consumption on time since Social Security benefits were received in order to test for a drop in consumption over the pay cycle. The following model is fitted to the data:

$$
\begin{aligned}
\log c_{i}= & \alpha+\psi_{f e}+\gamma \text { Nosave }_{i}+\sum_{t=2}^{5} \varphi_{t} \text { Week_t }_{i} \\
& +\sum_{t=2}^{5} \pi_{t} \text { Nosave }_{i} \times \text { Week }_{-} t_{i}+\mathbf{X}_{i}^{\prime} \theta+\varepsilon_{i} \\
\psi_{f e}= & \eta_{m}+\eta_{y}+\xi_{d}+\nu_{r},
\end{aligned}
$$

where $N_{\text {osave }}$ is a dummy equal to one if household $i$ has less than $\$ 5,000$ in liquid assets, and Week_t $t_{i}$ is a dummy equal to one if household $i$ most recently received Social Security benefits $t$ weeks ago. $\mathbf{X}_{i}$ is the same vector of household characteristics used to produce the graphs. The term $\psi_{f} \hat{e}$ contains month effects $\eta_{m}$, year effects $\eta_{y}$, day of the week effects $\xi_{d}$, and region effects $\nu_{r}$. This specification differs from the adjusted local linear regression graphs in that it does not assume that $\mathbf{X}_{i}$ and $\psi_{f} \hat{e}$ are orthogonal to time since benefits were received.

The OLS estimated coefficients $\hat{\varphi}_{t}$ measure the average percentage change in consumption common to savers and nonsavers. The estimates $\hat{\pi}_{t}$ on the interaction measure the percentage change in consumption of nonsavers between the first and $t^{\text {th }}$ week after receiving pay, relative to savers. If discounting is exponential, then logconsumption would depend linearly on time elapsed since checks were received (this is true even if households cannot transfer income across months), and this would give rise to linearly decreasing coefficients. The slope of log consumption would be $\log (\delta) / \rho$. For reasonable values of daily discount rates and intertemporal rates of substitution, 16 the $\varphi_{t}$ 's would be close to zero, and the $\pi_{t}$ 's would be zero. Savers and nonsavers would consume different levels, but the slope would always be the same. If, instead, the heterogeneity was in terms of $\delta$ or $\rho$, the slopes of the consumption profiles across the two groups would be different but still linear, that is, the $\pi_{t}$ 's would be on a straight line, as would the $\varphi_{t}$ 's.

While the focus of our paper is estimating the shape of the consumption profile over the month, we also estimate a version of the model where the change in log consumption over time is restricted to be linear.

$$
\begin{aligned}
\ln c_{i} & =\alpha+\psi_{f e}+\gamma \times \text { Nosave }_{i}+\varphi t_{i}+\pi t_{i} \times \text { Nosave }_{i}+\mathbf{X}_{i}^{\prime} \theta+\varepsilon_{i} \\
\psi_{f e} & =\eta_{m}+\xi_{d}+\nu_{r},
\end{aligned}
$$

${ }^{16} \rho$ is believed to be around four and typically not smaller than one. 
Table 3-Consumption Over the Pay Cycle by Savings Categories

\begin{tabular}{|c|c|c|c|c|c|c|}
\hline & \multicolumn{3}{|c|}{ Nonsavers } & \multicolumn{3}{|c|}{ Savers } \\
\hline & (1) & (2) & (3) & (4) & (5) & (6) \\
\hline \multicolumn{7}{|l|}{ Discount } \\
\hline $1-\beta$ & $\begin{array}{l}0.061 \\
(0.024) * *\end{array}$ & & $\begin{array}{c}0.085 \\
(0.055)^{*}\end{array}$ & $\begin{array}{r}-0.014 \\
(0.026)\end{array}$ & & $\begin{array}{c}0.025 \\
(0.059)\end{array}$ \\
\hline $1-\delta$ & & $\begin{array}{l}0.005 \\
(0.003)^{* *}\end{array}$ & $\begin{array}{c}-0.003 \\
(0.008)\end{array}$ & & $\begin{array}{r}-0.002 \\
(0.003)\end{array}$ & $\begin{array}{r}-0.005 \\
(0.007)\end{array}$ \\
\hline Observations & 399 & 399 & 399 & 346 & 346 & 346 \\
\hline$R^{2}$ & 0.214 & 0.210 & 0.214 & 0.214 & 0.210 & 0.214 \\
\hline
\end{tabular}

Notes: Estimated on CSFII data that is restricted to households with individuals older than 62 obtaining Social Security income that is at least 80 percent of total income. Savers are households with cash, savings or checking accounts, stocks, bonds, mutual funds and certificates of deposit worth at least $\$ 5,000$. All regressions control for usual monthly food expenditures, gender, household size, age, an age-gender interaction, health indicators, highest year of schooling completed (with a dummy variable for missing values), height, race, retirement status, a dummy indicating whether the respondent receives food stamps, and additional dummy variables indicating month, day of the week, survey year, region, typical shopping frequency, and MSA status. Standard errors clustered by survey stratum in parentheses.

** Indicates a 5 percent significance of a one-sided (positive) test.

* Indicates a 10 percent significance of a one-sided (positive) test.

where here $t_{i}$ is the number of days since checks were received. The average daily percentage change in consumption common to savers and nonsavers is given by the coefficient $\varphi$ and the average daily percentage decline in consumption of nonsavers relative to savers is given by $\pi$. Although the graphical evidence of Section IIIA reveals that the change in log consumption amongst Social Security benefits recipients does not appear to be linear, this specification makes our results comparable to those of Shapiro (2005). He uses this linear specification to estimate the daily percentage change in consumption for food stamp recipients, estimates a daily decline in consumption of 0.45 percent, and shows that a standard lifecycle model would require implausibly small annual discount factors or implausibly large intertemporal elasticities of substitution to explain this decline.

Table 4 contains the results of estimating the unconstrained model for various consumption measures. Column 1 reports the relative change in energy (total caloric intake) over the pay cycle. The estimates in column 1 imply that the difference in caloric intake between savers and nonsavers is insignificantly different from zero during the week immediately after checks are received, with a $t$-statistic on the difference of 0.56 . The changes in consumption for the savers relative to their first week consumption are positive and insignificantly different from zero for each period. The consumption for nonsavers drops dramatically relative to savers, particularly during the final week of the pay period. During the third week, the difference increases to -11 percent. During the last week of the pay period this difference increases to -35 percent (significantly different from zero at the 0.05 level).

Column (2) presents estimates from a linear probability model of eating a meal out of the household. During the first week of the pay period, nonsavers eat out 6 percentage points less than savers, and, though insignificant at conventional levels, this number increases in magnitude to 19 percentage points in the last week of the month. Column 3 presents the results for the quality index, which is basically 
Table 4-Consumption Over the Pay Cycle by Savings Categories

\begin{tabular}{|c|c|c|c|c|c|c|c|}
\hline & $\begin{array}{c}\log \\
\text { energy } \\
(1)\end{array}$ & $\begin{array}{c}\text { Probability } \\
\text { eating out } \\
\text { (2) }\end{array}$ & $\begin{array}{c}\log \\
\text { quality } \\
\text { (3) }\end{array}$ & $\begin{array}{c}\text { Fraction } \\
\text { saturated fat } \\
(4)\end{array}$ & $\begin{array}{c}\log \\
\text { cholesterol } \\
(5)\end{array}$ & $\begin{array}{c}\log \\
\text { fiber } \\
(6)\end{array}$ & $\begin{array}{c}\log \\
\text { vitamins } \\
(7)\end{array}$ \\
\hline No savings & $\begin{array}{l}2.76 \\
(7.03)\end{array}$ & $\begin{array}{c}-6.13 \\
(9.10)\end{array}$ & $\begin{array}{c}0.07 \\
(2.39)\end{array}$ & $\begin{array}{r}-0.07 \\
(1.72)\end{array}$ & $\begin{array}{c}8.39 \\
(24.47)\end{array}$ & $\begin{array}{l}-1.81 \\
(11.88)\end{array}$ & $\begin{array}{c}2.04 \\
(9.19)\end{array}$ \\
\hline Week 2 & $\begin{array}{c}5.85 \\
(7.54)\end{array}$ & $\begin{array}{c}1.24 \\
(8.24)\end{array}$ & $\begin{array}{r}-0.88 \\
(2.12)\end{array}$ & $\begin{array}{c}-0.39 \\
(1.55)\end{array}$ & $\begin{array}{c}7.92 \\
(19.60)\end{array}$ & $\begin{array}{r}-12.78 \\
(9.44)\end{array}$ & $\begin{array}{l}-16.84 \\
(7.83)^{* *}\end{array}$ \\
\hline Week 3 & $\begin{array}{c}8.04 \\
(7.86)\end{array}$ & $\begin{array}{c}8.60 \\
(8.43)\end{array}$ & $\begin{array}{c}0.41 \\
(2.07)\end{array}$ & $\begin{array}{c}-2.41 \\
(1.63)\end{array}$ & $\begin{array}{c}7.45 \\
(15.85)\end{array}$ & $\begin{array}{l}-8.39 \\
(10.36)\end{array}$ & $\begin{array}{r}-11.11 \\
(7.16)\end{array}$ \\
\hline Week 4 & $\begin{array}{c}6.10 \\
(7.12)\end{array}$ & $\begin{array}{c}-1.76 \\
(7.18)\end{array}$ & $\begin{array}{c}2.77 \\
(2.09)\end{array}$ & $\begin{array}{c}-1.56 \\
(1.59)\end{array}$ & $\begin{array}{l}-7.60 \\
(20.89)\end{array}$ & $\begin{array}{c}-5.89 \\
(8.96)\end{array}$ & $\begin{array}{c}-1.04 \\
(6.32)\end{array}$ \\
\hline Week 5 & $\begin{array}{l}15.10 \\
(9.76)\end{array}$ & $\begin{array}{c}7.78 \\
(13.37)\end{array}$ & $\begin{array}{c}1.16 \\
(2.80)\end{array}$ & $\begin{array}{r}-0.55 \\
(2.11)\end{array}$ & $\begin{array}{c}6.22 \\
(20.77)\end{array}$ & $\begin{array}{r}4.80 \\
(12.72)\end{array}$ & $\begin{array}{c}2.59 \\
(11.06)\end{array}$ \\
\hline $\mathrm{NS} \times$ week 2 & $\begin{array}{l}-9.43 \\
(10.21)\end{array}$ & $\begin{array}{l}-2.31 \\
(10.46)\end{array}$ & $\begin{array}{c}-0.61 \\
(2.75)\end{array}$ & $\begin{array}{c}0.57 \\
(2.20)\end{array}$ & $\begin{array}{c}7.16 \\
(26.51)\end{array}$ & $\begin{array}{l}-2.30 \\
(13.53)\end{array}$ & $\begin{array}{c}1.38 \\
(10.06)\end{array}$ \\
\hline NS $\times$ week 3 & $\begin{array}{c}-11.35 \\
(10.26)\end{array}$ & $\begin{array}{r}-11.90 \\
(10.76)\end{array}$ & $\begin{array}{c}-3.71 \\
(2.84)\end{array}$ & $\begin{array}{l}2.96 \\
(2.04)\end{array}$ & $\begin{array}{c}8.41 \\
(25.68)\end{array}$ & $\begin{array}{r}-12.41 \\
(17.32)\end{array}$ & $\begin{array}{l}-8.03 \\
(11.76)\end{array}$ \\
\hline NS $\times$ week 4 & $\begin{array}{c}-10.73 \\
(10.27)\end{array}$ & $\begin{array}{c}-3.64 \\
(9.56)\end{array}$ & $\begin{array}{r}-3.72 \\
(2.55)\end{array}$ & $\begin{array}{c}2.82 \\
(2.08)\end{array}$ & $\begin{array}{c}14.42 \\
(26.87)\end{array}$ & $\begin{array}{l}-8.53 \\
(14.63)\end{array}$ & $\begin{array}{c}-6.28 \\
(8.94)\end{array}$ \\
\hline $\mathrm{NS} \times$ week 5 & $\begin{array}{l}-35.20 \\
(14.35) * *\end{array}$ & $\begin{array}{r}-19.48 \\
(15.87)\end{array}$ & $\begin{array}{r}-2.97 \\
(3.73)\end{array}$ & $\begin{array}{l}1.99 \\
(2.62)\end{array}$ & $\begin{array}{c}21.53 \\
(30.15)\end{array}$ & $\begin{array}{r}-20.26 \\
(17.20)\end{array}$ & $\begin{array}{r}-14.30 \\
(13.44)\end{array}$ \\
\hline log energy & & & $\begin{array}{l}0.17 \\
(0.01)^{* * * *}\end{array}$ & & $\begin{array}{l}1.21 \\
(0.12)^{* * * *}\end{array}$ & $\begin{array}{l}0.80 \\
(0.07)^{* * * *}\end{array}$ & $\begin{array}{l}0.88 \\
(0.05) * * *\end{array}$ \\
\hline $\begin{array}{l}\text { Observations } \\
R^{2}\end{array}$ & $\begin{array}{c}745 \\
0.26\end{array}$ & $\begin{array}{l}745 \\
0.11\end{array}$ & $\begin{array}{l}738 \\
0.47\end{array}$ & $\begin{array}{l}745 \\
0.10\end{array}$ & $\begin{array}{c}742 \\
0.33\end{array}$ & $\begin{array}{l}745 \\
0.42\end{array}$ & $\begin{array}{l}745 \\
0.53\end{array}$ \\
\hline \multicolumn{8}{|c|}{ Implied effect for nonsavers } \\
\hline Week 2 & $\begin{array}{c}-3.58 \\
(7.55)\end{array}$ & $\begin{array}{r}-1.06 \\
(6.53)\end{array}$ & $\begin{array}{r}-1.49 \\
(1.95)\end{array}$ & $\begin{array}{c}0.18 \\
(1.50)\end{array}$ & $\begin{array}{c}15.08 \\
(17.73)\end{array}$ & $\begin{array}{r}-15.08 \\
(9.86)\end{array}$ & $\begin{array}{c}-15.46 \\
(8.13) *\end{array}$ \\
\hline Week 3 & $\begin{array}{c}-3.31 \\
(7.64)\end{array}$ & $\begin{array}{r}-3.30 \\
(6.36)\end{array}$ & $\begin{array}{l}-3.30 \\
(1.88) *\end{array}$ & $\begin{array}{c}0.55 \\
(1.30)\end{array}$ & $\begin{array}{l}15.85 \\
(17.87)\end{array}$ & $\begin{array}{r}-20.79 \\
(13.28)\end{array}$ & $\begin{array}{l}-19.14 \\
(8.79) * *\end{array}$ \\
\hline Week 4 & $\begin{array}{c}-4.63 \\
(7.78)\end{array}$ & $\begin{array}{r}-5.40 \\
(6.62)\end{array}$ & $\begin{array}{r}-0.95 \\
(1.70)\end{array}$ & $\begin{array}{c}1.27 \\
(1.25)\end{array}$ & $\begin{array}{c}6.82 \\
(17.92)\end{array}$ & $\begin{array}{r}-14.42 \\
(10.27)\end{array}$ & $\begin{array}{c}-7.32 \\
(8.00)\end{array}$ \\
\hline Week 5 & $\begin{array}{l}-20.10 \\
(8.68) * *\end{array}$ & $\begin{array}{r}-11.70 \\
(6.25) *\end{array}$ & $\begin{array}{r}-1.81 \\
(2.78)\end{array}$ & $\begin{array}{c}1.44 \\
(1.83)\end{array}$ & $\begin{array}{c}27.75 \\
(26.37)\end{array}$ & $\begin{array}{r}-15.45 \\
(13.17)\end{array}$ & $\begin{array}{r}-11.71 \\
(7.95)\end{array}$ \\
\hline
\end{tabular}

Notes: Estimated on CSFII data is restricted to households with individuals older than 62 obtaining Social Security income that is at least 80 percent of total income. Savings is defined as having cash, savings or checking accounts, stocks, bonds, mutual funds and certificates of deposit worth at least $\$ 5,000$. All regressions control for the variables listed in the footnote of Table 4 . Standard errors are clustered by survey stratum in parentheses.

*** Significant at the 1 percent level.

** Significant at the 5 percent level.

* Significant at the 10 percent level.

constant over the pay period. Columns 4-7 present other measures of quality including the fraction of fat that is saturated, cholesterol, fiber, and vitamins (conditional on total calories). While the point estimates suggest cholesterol intake increases at the end of the month, and fiber and vitamin intake decreases for nonsavers, the estimates on the interaction terms are all insignificantly different from zero.

In order to conduct inference on the consumption profiles of nonsavers, the lower panel of Table 4 presents the implied total estimates for nonsavers $\left(\hat{\varphi}_{t}+\hat{\pi}_{t}\right)$ along with standard errors. Consumption is 24 percent lower during the last week of the 
Table 5-Consumption Over the Pay Cycle by Savings Categories: Linear Model

\begin{tabular}{lccccccc}
\hline \hline & $\begin{array}{c}\text { log } \\
\text { energy } \\
(1)\end{array}$ & $\begin{array}{c}\text { Probability } \\
\text { eating out } \\
(2)\end{array}$ & $\begin{array}{c}\text { log } \\
\text { quality } \\
(3)\end{array}$ & $\begin{array}{c}\text { Fraction } \\
\text { saturated fat } \\
(4)\end{array}$ & $\begin{array}{c}\text { log } \\
\text { cholesterol } \\
(5)\end{array}$ & $\begin{array}{c}\text { log } \\
\text { fiber } \\
(6)\end{array}$ & $\begin{array}{c}\text { log } \\
\text { vitamins } \\
(7)\end{array}$ \\
\hline Time & 0.26 & 0.13 & 0.08 & -0.03 & -0.03 & -0.01 & 0.18 \\
& $(0.28)$ & $(0.30)$ & $(0.08)$ & $(0.06)$ & $(0.72)$ & $(0.33)$ & $(0.27)$ \\
Time $\times$ no savings & -0.70 & -0.51 & -0.14 & 0.09 & 0.64 & -0.49 & -0.49 \\
& $(0.38 * *$ & $(0.38)$ & $(0.09)$ & $(0.07)$ & $(1.04)$ & $(0.53)$ & $(0.36)$ \\
No savings & 2.73 & -4.22 & 0.19 & 0.25 & 7.28 & -0.80 & 6.10 \\
& $(6.12)$ & $(7.82)$ & $(1.81)$ & $(1.37)$ & $(20.85)$ & $(9.57)$ & $(7.60)$ \\
log energy & & & 0.17 & & 1.21 & 0.80 & 0.87 \\
& & & $(0.01) * * *$ & & $(0.12) * * *$ & $(0.07) * * *$ & $(0.05)^{* * * *}$ \\
Observations & 745 & 745 & 738 & 745 & 742 & 745 & 745 \\
$R^{2}$ & 0.26 & 0.11 & 0.46 & 0.10 & 0.33 & 0.42 & 0.51 \\
\hline Implied effect for nonsavers & -0.44 & -0.38 & -0.06 & 0.05 & 0.61 & -0.50 & -0.32 \\
Time (nonsavers) & $(0.27)$ & $(0.22) *$ & $(0.07)$ & $(0.04)$ & $(0.75)$ & $(0.39)$ & $(0.28)$ \\
\hline
\end{tabular}

Notes: Estimated on CSFII data that is restricted to households with individuals older than 62 obtaining Social Security income that is at least 80 percent of total income. Savings is defined as having cash, savings or checking accounts, stocks, bonds, mutual funds and certificates of deposit worth at least $\$ 5,000$. All regressions control for the variables listed in the footnote of Table 4. Standard errors clustered by survey stratum in parentheses.

*** Significant at the 1 percent level.

* Significant at the 10 percent level.

pay period relative to the first week, and this is significant at the 0.05 level. Further, the likelihood of eating out is 11.7 percentage points lower in the final week relative to the first week for nonsavers, and this is significant at the 0.10 level. The other quality measures are less precisely estimated, but tend to be decreasing over the month if anything.

Table 5 contains the results of estimating the linear model. Caloric intake rises by an insignificantly different from zero 0.26 percent per day for savers and falls by 0.70 percent per day for nonsavers relative to savers on average. Taken together these estimates imply that caloric intake falls by 0.44 percent per day for nonsavers. This estimate of the daily decline in consumption for Social Security recipients with little savings is remarkably similar to that in Shapiro's 2005 study of food stamp recipients. He finds consumption declines of 0.45 percent per day for recipients after they receive their food stamps. The bottom panel of Table 5 presents the implied estimate for nonsavers. The daily decline in consumption for nonsavers is statistically significant at the 0.10 level.

\section{Alternative Explanations and Additional Evidence}

The results thus far demonstrate that consumption is higher immediately after Social Security benefits are paid than at the end of the pay cycle for nonsavers. A concern is that consumption is not falling because households are exhausting their budget over the pay cycle, but because of other determinants of consumption correlated with day of the month. To explore this possibility, we reestimate the model for a placebo sample of households in which the oldest member is not eligible for Social Security benefits. If 
Table 6-Consumption Over the Pay Cycle by Savings Categories for the Placebo Sample

\begin{tabular}{|c|c|c|c|c|c|c|c|}
\hline & $\begin{array}{l}\log \\
\text { energy } \\
(1)\end{array}$ & $\begin{array}{l}\text { Probability } \\
\text { eating out } \\
\text { (2) }\end{array}$ & $\begin{array}{c}\log \\
\text { quality } \\
\text { (3) }\end{array}$ & $\begin{array}{c}\text { Fraction } \\
\text { saturated fat } \\
\text { (4) }\end{array}$ & $\begin{array}{c}\log \\
\text { cholesterol } \\
(5)\end{array}$ & $\begin{array}{l}\log \\
\text { fiber } \\
(6)\end{array}$ & $\begin{array}{c}\log \\
\text { vitamins } \\
(7)\end{array}$ \\
\hline No savings & $\begin{array}{r}-10.10 \\
(6.37)\end{array}$ & $\begin{array}{c}-5.57 \\
(8.76)\end{array}$ & $\begin{array}{r}-3.23 \\
(2.16)\end{array}$ & $\begin{array}{l}3.70 \\
(1.56) * *\end{array}$ & $\begin{array}{r}2.30 \\
(11.91)\end{array}$ & $\begin{array}{r}-6.56 \\
(8.74)\end{array}$ & $\begin{array}{r}-10.42 \\
(6.15) *\end{array}$ \\
\hline Week 2 & $\begin{array}{c}-3.78 \\
(6.87)\end{array}$ & $\begin{array}{c}3.72 \\
(8.57)\end{array}$ & $\begin{array}{c}0.33 \\
(1.72)\end{array}$ & $\begin{array}{c}0.68 \\
(1.25)\end{array}$ & $\begin{array}{l}-7.97 \\
(11.44)\end{array}$ & $\begin{array}{l}2.76 \\
(9.12)\end{array}$ & $\begin{array}{c}5.47 \\
(6.07)\end{array}$ \\
\hline Week 3 & $\begin{array}{r}-0.49 \\
(6.74)\end{array}$ & $\begin{array}{c}4.19 \\
(7.81)\end{array}$ & $\begin{array}{r}-0.30 \\
(1.61)\end{array}$ & $\begin{array}{c}-0.55 \\
(0.95)\end{array}$ & $\begin{array}{c}-7.32 \\
(9.40)\end{array}$ & $\begin{array}{c}-7.57 \\
(8.67)\end{array}$ & $\begin{array}{c}1.85 \\
(4.90)\end{array}$ \\
\hline Week 4 & $\begin{array}{c}7.83 \\
(7.20)\end{array}$ & $\begin{array}{c}8.24 \\
(7.99)\end{array}$ & $\begin{array}{r}-0.34 \\
(1.59)\end{array}$ & $\begin{array}{c}2.23 \\
(1.53)\end{array}$ & $\begin{array}{c}-10.03 \\
(11.46)\end{array}$ & $\begin{array}{l}10.17 \\
(7.33)\end{array}$ & $\begin{array}{r}1.86 \\
(4.16)\end{array}$ \\
\hline Week 5 & $\begin{array}{c}1.82 \\
(10.56)\end{array}$ & $\begin{array}{l}-9.77 \\
(12.13)\end{array}$ & $\begin{array}{c}1.68 \\
(3.54)\end{array}$ & $\begin{array}{l}3.55 \\
(1.92)^{*}\end{array}$ & $\begin{array}{l}-57.29 \\
(23.50) * *\end{array}$ & $\begin{array}{c}11.48 \\
(10.24)\end{array}$ & $\begin{array}{c}12.89 \\
(11.40)\end{array}$ \\
\hline $\mathrm{NS} \times$ week 2 & $\begin{array}{c}14.07 \\
(10.72)\end{array}$ & $\begin{array}{c}1.07 \\
(12.98)\end{array}$ & $\begin{array}{c}3.36 \\
(2.44)\end{array}$ & $\begin{array}{l}-3.65 \\
(2.12) *\end{array}$ & $\begin{array}{r}-13.39 \\
(18.65)\end{array}$ & $\begin{array}{c}16.25 \\
(14.18)\end{array}$ & $\begin{array}{c}9.26 \\
(7.98)\end{array}$ \\
\hline NS $\times$ week 3 & $\begin{array}{l}21.58 \\
(10.48) * *\end{array}$ & $\begin{array}{l}-9.77 \\
(12.83)\end{array}$ & $\begin{array}{c}2.84 \\
(3.13)\end{array}$ & $\begin{array}{c}-3.24 \\
(2.07)\end{array}$ & $\begin{array}{c}3.39 \\
(19.04)\end{array}$ & $\begin{array}{c}21.52 \\
(15.51)\end{array}$ & $\begin{array}{l}31.46 \\
(13.40) * *\end{array}$ \\
\hline NS $\times$ week 4 & $\begin{array}{l}-2.40 \\
(10.69)\end{array}$ & $\begin{array}{l}-0.01 \\
(11.12)\end{array}$ & $\begin{array}{c}0.12 \\
(3.06)\end{array}$ & $\begin{array}{l}-4.90 \\
(2.39)^{* *}\end{array}$ & $\begin{array}{l}-2.19 \\
(16.47)\end{array}$ & $\begin{array}{c}-15.74 \\
(13.67)\end{array}$ & $\begin{array}{c}3.44 \\
(10.15)\end{array}$ \\
\hline NS $\times$ week 5 & $\begin{array}{c}23.92 \\
(17.68)\end{array}$ & $\begin{array}{c}47.08 \\
(23.94)^{*}\end{array}$ & $\begin{array}{c}4.72 \\
(4.53)\end{array}$ & $\begin{array}{c}-4.24 \\
(3.09)\end{array}$ & $\begin{array}{c}45.34 \\
(38.53)\end{array}$ & $\begin{array}{c}-14.78 \\
(19.20)\end{array}$ & $\begin{array}{r}0.20 \\
(15.13)\end{array}$ \\
\hline log energy & & & $\begin{array}{l}0.06 \\
(0.01)^{* * * *}\end{array}$ & & $\begin{array}{l}1.04 \\
(0.08)^{* * * *}\end{array}$ & $\begin{array}{l}0.69 \\
(0.07) * * *\end{array}$ & $\begin{array}{l}0.72 \\
(0.04)^{* * *}\end{array}$ \\
\hline $\begin{array}{l}\text { Observations } \\
R^{2}\end{array}$ & 659 & 659 & 652 & 659 & 654 & 659 & 659 \\
\hline
\end{tabular}

Notes: Estimated on CSFII data that is restricted to households with individuals aged 52 to 61 . Savings is defined as having cash, savings or checking accounts, stocks, bonds, mutual funds and certificates of deposit worth at least $\$ 5,000$. All regressions control for the variables listed in the footnote of Table 4 . Standard errors are clustered by survey stratum in parentheses.

*** Significant at the 1 percent level.

**Significant at the 5 percent level.

* Significant at the 10 percent level.

the coefficients on the week dummies are zero, then the previous results are unlikely to stem from day of the month effects, other than time since Social Security benefits were received. Table 6 contains the results for households in which the oldest member is between 52 and 61 years of age. Consumption does not decline over the Social Security pay cycle, nor does it decrease relative to the households with savings. Table 7 contains the results of estimating the linear model on the placebo sample, again. Consumption does not decline over the pay cycle.

Table 8 presents the results of estimating the unconstrained model for different subsamples of the data. Column 1 reports the results for the full sample for ease of reference. An alternative explanation for declining consumption over the month is intra-household competition for resources. Sixty percent of the households in our sample contain more than one person. Among nonhousehold head interviewees in our sample, 83 percent were the spouse of the head of the household, 9 percent were parents of the head of the household, and all but one interviewee was related in some way to the head of the household. Columns 2 and 3 present results from separately estimating the model for single- and multi-person households. Doing so significantly 
Table 7-Consumption Over the Pay Cycle by Savings Categories for the Placebo Sample

\begin{tabular}{lccccccc}
\hline \hline & $\begin{array}{c}\text { log } \\
\text { energy } \\
(1)\end{array}$ & $\begin{array}{c}\text { Probability } \\
\text { eating out } \\
(2)\end{array}$ & $\begin{array}{c}\text { log } \\
\text { quality } \\
(3)\end{array}$ & $\begin{array}{c}\text { Fraction } \\
\text { saturated fat } \\
(4)\end{array}$ & $\begin{array}{c}\text { log } \\
\text { cholesterol } \\
(5)\end{array}$ & $\begin{array}{c}\text { log } \\
\text { fiber } \\
(6)\end{array}$ & $\begin{array}{c}\text { log } \\
\text { vitamins } \\
(7)\end{array}$ \\
\hline Time & 0.31 & 0.26 & 0.02 & 0.10 & -1.02 & 0.38 & 0.18 \\
& $(0.29)$ & $(0.29)$ & $(0.07)$ & $(0.05) *$ & $(0.40) * *$ & $(0.28)$ & $(0.20)$ \\
No savings & -2.91 & -7.00 & -1.76 & 2.40 & -8.07 & 9.24 & -3.71 \\
& $(6.86)$ & $(8.18)$ & $(2.36)$ & $(1.50)$ & $(12.25)$ & $(8.61)$ & $(5.84)$ \\
Time $\times$ no savings & 0.10 & 0.31 & 0.02 & -0.12 & 0.67 & -0.81 & 0.09 \\
& $(0.46)$ & $(0.49)$ & $(0.13)$ & $(0.09)$ & $(0.71)$ & $(0.61)$ & $(0.41)$ \\
log energy & & & 0.06 & & 1.04 & 0.70 & 0.72 \\
& & & $(0.01) * * *$ & & $(0.08) * * *$ & $(0.07) * * *$ & $(0.04) * * *$ \\
Observations & 659 & 659 & 652 & 659 & 654 & 659 & 659 \\
$R^{2}$ & 0.30 & 0.12 & 0.24 & 0.14 & 0.40 & 0.36 & 0.52 \\
\hline
\end{tabular}

Notes: Estimated on CSFII data is restricted to households with individuals aged 52 to 61. Savings is defined as having cash, savings or checking accounts, stocks, bonds, mutual funds and certificates of deposit worth at least $\$ 5,000$. All regressions control for the variables listed in the footnote of Table 4. Standard errors are clustered by survey stratum in parentheses.

*** Significant at the 1 percent level.

**Significant at the 5 percent level.

* Significant at the 10 percent level.

reduces the sample size, and the results are mixed for single-person households. While consumption does fall in the final days of the pay period for single people, this estimate is not precisely estimated, and an imprecisely estimated small increase in consumption for nonsavers relative to savers was found in the fourth week. The results for multi-person households are much more similar to the results from the full sample. In two separate questions, the CSFII asks respondents whether they are meal planners for their household, and whether they do the majority of food shopping. If individuals were competing for food, then respondents who do the shopping would have an obvious strategic advantage over those who do not do the shopping. In columns 4 and 5, we find no strong differences in consumption patterns across these groups, casting doubt on the explanation based on uncooperative behavior among household members.

Households that have little savings and heavy dependence on Social Security may be more susceptible to unexpected expenses than those with savings. Households with savings can draw down their savings and continue their usual consumption, while those without savings may be forced to go with little food if they are liquidity constrained. CSFII respondents were asked if they had enough food over the past three months. As long as past shocks are correlated with current shocks we can test the importance of uncertainty. Column 6 presents estimates of the model for the subsample of respondents that did not recently run out of food, and column 7 presents estimates for those that did. Curiously, consumption falls dramatically for nonsavers who had enough food over the past three months and remains constant for nonsavers who did not have enough food sometime over the past three months. Consumption slightly rises over the month for savers who have not run out of food recently and falls for those who had run out. This evidence suggests that for consumers who face 
Table 8-Consumption Over the Pay Cycle by Savings Categories for Subgroups

\begin{tabular}{|c|c|c|c|c|c|c|c|}
\hline & \multirow{2}{*}{$\begin{array}{c}\text { Full sample } \\
(1)\end{array}$} & \multicolumn{2}{|c|}{ Household size } & \multirow{2}{*}{$\begin{array}{c}\begin{array}{c}\text { Enough } \\
\text { food }\end{array} \\
\text { Yes } \\
(4)\end{array}$} & \multirow{2}{*}{$\begin{array}{c}\begin{array}{c}\text { Not enough } \\
\text { food }\end{array} \\
\text { No } \\
(5)\end{array}$} & \multicolumn{2}{|c|}{ Meal planner } \\
\hline & & $\begin{array}{l}=1 \\
(2)\end{array}$ & $\begin{array}{l}>1 \\
(3)\end{array}$ & & & $\begin{array}{l}\text { Yes } \\
(6)\end{array}$ & $\begin{array}{l}\text { No } \\
(7)\end{array}$ \\
\hline No savings & $\begin{array}{l}2.76 \\
(7.03)\end{array}$ & $\begin{array}{l}-2.74 \\
(10.81)\end{array}$ & $\begin{array}{c}8.27 \\
(8.43)\end{array}$ & $\begin{array}{l}6.67 \\
(7.55)\end{array}$ & $\begin{array}{l}-30.44 \\
(13.10)^{* *}\end{array}$ & $\begin{array}{r}3.69 \\
(9.17)\end{array}$ & $\begin{array}{c}10.78 \\
(13.11)\end{array}$ \\
\hline Week 2 & $\begin{array}{l}5.85 \\
(7.54)\end{array}$ & $\begin{array}{c}12.65 \\
(10.96)\end{array}$ & $\begin{array}{r}-1.34 \\
(6.72)\end{array}$ & $\begin{array}{c}8.49 \\
(8.34)\end{array}$ & $\begin{array}{l}-39.39 \\
(16.23) * *\end{array}$ & $\begin{array}{c}6.57 \\
(9.24)\end{array}$ & $\begin{array}{r}6.09 \\
(10.81)\end{array}$ \\
\hline Week 3 & $\begin{array}{c}8.04 \\
(7.86)\end{array}$ & $\begin{array}{c}10.46 \\
(12.20)\end{array}$ & $\begin{array}{c}6.91 \\
(10.47)\end{array}$ & $\begin{array}{c}5.11 \\
(8.40)\end{array}$ & $\begin{array}{c}5.74 \\
(14.76)\end{array}$ & $\begin{array}{c}7.97 \\
(9.31)\end{array}$ & $\begin{array}{c}12.30 \\
(12.80)\end{array}$ \\
\hline Week 4 & $\begin{array}{c}6.10 \\
(7.12)\end{array}$ & $\begin{array}{l}-6.33 \\
(17.61)\end{array}$ & $\begin{array}{c}6.97 \\
(8.48)\end{array}$ & $\begin{array}{l}5.69 \\
(7.56)\end{array}$ & $\begin{array}{l}-4.16 \\
(16.59)\end{array}$ & $\begin{array}{l}10.58 \\
(8.77)\end{array}$ & $\begin{array}{c}-2.99 \\
(9.07)\end{array}$ \\
\hline Week 5 & $\begin{array}{l}15.10 \\
(9.76)\end{array}$ & $\begin{array}{c}3.42 \\
(18.52)\end{array}$ & $\begin{array}{c}10.66 \\
(10.63)\end{array}$ & $\begin{array}{l}18.35 \\
(9.77)^{*}\end{array}$ & $\begin{array}{l}-66.66 \\
(30.81)^{* *}\end{array}$ & $\begin{array}{c}19.81 \\
(12.36)\end{array}$ & $\begin{array}{c}4.96 \\
(14.61)\end{array}$ \\
\hline NS $\times$ week 2 & $\begin{array}{l}-9.43 \\
(10.21)\end{array}$ & $\begin{array}{c}-22.81 \\
(13.23) *\end{array}$ & $\begin{array}{l}-0.65 \\
(11.86)\end{array}$ & $\begin{array}{r}-18.09 \\
(11.22)\end{array}$ & $\begin{array}{l}38.40 \\
(21.57)^{*}\end{array}$ & $\begin{array}{c}-14.11 \\
(11.90)\end{array}$ & $\begin{array}{l}-9.17 \\
(15.66)\end{array}$ \\
\hline NS $\times$ week 3 & $\begin{array}{c}-11.35 \\
(10.26)\end{array}$ & $\begin{array}{l}-2.95 \\
(15.97)\end{array}$ & $\begin{array}{c}-17.66 \\
(12.60)\end{array}$ & $\begin{array}{c}-19.05 \\
(11.64)\end{array}$ & $\begin{array}{c}12.54 \\
(18.43)\end{array}$ & $\begin{array}{r}-10.39 \\
(12.37)\end{array}$ & $\begin{array}{r}-24.00 \\
(17.94)\end{array}$ \\
\hline NS $\times$ week 4 & $\begin{array}{c}-10.73 \\
(10.27)\end{array}$ & $\begin{array}{c}17.07 \\
(20.10)\end{array}$ & $\begin{array}{l}-33.63 \\
(15.38) * *\end{array}$ & $\begin{array}{r}-12.50 \\
(10.88)\end{array}$ & $\begin{array}{c}14.37 \\
(19.86)\end{array}$ & $\begin{array}{c}-11.96 \\
(12.48)\end{array}$ & $\begin{array}{c}-24.08 \\
(19.99)\end{array}$ \\
\hline NS $\times$ week 5 & $\begin{array}{l}-35.20 \\
(14.35) * *\end{array}$ & $\begin{array}{c}-15.60 \\
(22.34)\end{array}$ & $\begin{array}{l}-36.71 \\
(14.47) * *\end{array}$ & $\begin{array}{l}-43.27 \\
(14.00) * * *\end{array}$ & $\begin{array}{c}64.73 \\
(35.79)^{*}\end{array}$ & $\begin{array}{l}-39.09 \\
(17.43)^{* *}\end{array}$ & $\begin{array}{c}-44.26 \\
(23.35)^{*}\end{array}$ \\
\hline $\begin{array}{l}\text { Observations } \\
R^{2}\end{array}$ & $\begin{array}{c}745 \\
0.26\end{array}$ & $\begin{array}{l}304 \\
0.30\end{array}$ & $\begin{array}{l}441 \\
0.37\end{array}$ & $\begin{array}{r}569 \\
0.29\end{array}$ & $\begin{array}{r}176 \\
0.49\end{array}$ & $\begin{array}{r}523 \\
0.25\end{array}$ & $\begin{array}{l}221 \\
0.39\end{array}$ \\
\hline
\end{tabular}

Notes: Estimated on CSFII data is restricted to households with individuals older than 62 obtaining Social Security income that is at least 80 percent of total income. Savings is defined as having cash, savings or checking accounts, stocks, bonds, mutual funds and certificates of deposit worth at least $\$ 5,000$. All regressions control for the variables listed in the footnote of Table 4. Standard errors are clustered by survey stratum in parentheses.

*** Significant at the 1 percent level.

** Significant at the 5 percent level.

* Significant at the 10 percent level.

larger uncertainties, the precautionary motives that give rise to an increasing consumption pattern dominate the present bias. It also suggests that greater vulnerability to negative shocks does not entirely explain the shape of consumption profiles.

Alternatively, in the presence of expenditure shocks some consumers may be more willing to risk being subject to drastic reductions in consumption. In this case, the significant drop of those hit by negative shocks would drive all the results. Since shocks can be more easily absorbed at the beginning of the pay period than at the end, this model would generate heteroskedasticity with respect to elapsed time since check arrival. To test for heteroskedasticity, we first run a median regression. If the results were driven by a few outliers, the median effects would be lower. What we find, instead, is a significant 43 percent drop between week five and week one for nonsavers compared to savers. We also can reject heteroskedasticity using the Breush-Pagan test (at the 28 percent level) 17

\footnotetext{
${ }^{17}$ We regress the squared residuals from the NLS regression of nonsavers on the elapsed weeks dummies. $R^{2}$ times the number of observations has a chi-squared distribution with five degrees of freedom.
} 
Table 9-Consumption Over the Pay Cycle by Savings Categories Linear Model Using Different "Treatments."

\begin{tabular}{|c|c|c|c|c|c|c|}
\hline & \multicolumn{6}{|c|}{ "Distinguishing variable" } \\
\hline & $\begin{array}{c}\text { No } \\
\text { supplements } \\
(1)\end{array}$ & $\begin{array}{c}\text { Smoker } \\
(2)\end{array}$ & $\begin{array}{c}\text { Drinker } \\
\text { (3) }\end{array}$ & $\begin{array}{c}\text { Heavy } \\
\text { drinker } \\
(4)\end{array}$ & $\begin{array}{l}\text { Home } \\
\text { renter } \\
(5)\end{array}$ & $\begin{array}{c}\text { Frequent } \\
\text { shopper } \\
(6)\end{array}$ \\
\hline "Distinguishing variable" & $\begin{array}{c}3.88 \\
(7.90)\end{array}$ & $\begin{array}{l}17.09 \\
(9.66) *\end{array}$ & $\begin{array}{r}-0.85 \\
(6.44)\end{array}$ & $\begin{array}{c}64.59 \\
(47.26)\end{array}$ & $\begin{array}{c}6.59 \\
(8.17)\end{array}$ & $\begin{array}{c}3.83 \\
(10.87)\end{array}$ \\
\hline Week 2 & $\begin{array}{c}3.85 \\
(6.58)\end{array}$ & $\begin{array}{c}2.54 \\
(5.75)\end{array}$ & $\begin{array}{c}-1.98 \\
(6.22)\end{array}$ & $\begin{array}{c}2.08 \\
(5.45)\end{array}$ & $\begin{array}{c}6.61 \\
(5.61)\end{array}$ & $\begin{array}{c}-1.17 \\
(7.67)\end{array}$ \\
\hline Week 3 & $\begin{array}{c}5.19 \\
(7.35)\end{array}$ & $\begin{array}{c}3.94 \\
(5.93)\end{array}$ & $\begin{array}{c}-1.71 \\
(6.76)\end{array}$ & $\begin{array}{c}1.87 \\
(5.76)\end{array}$ & $\begin{array}{l}2.69 \\
(6.52)\end{array}$ & $\begin{array}{c}3.25 \\
(9.38)\end{array}$ \\
\hline Week 4 & $\begin{array}{c}4.72 \\
(6.40)\end{array}$ & $\begin{array}{c}3.66 \\
(5.52)\end{array}$ & $\begin{array}{c}-5.17 \\
(6.16)\end{array}$ & $\begin{array}{c}1.62 \\
(5.50)\end{array}$ & $\begin{array}{r}2.46 \\
(5.18)\end{array}$ & $\begin{array}{c}8.91 \\
(10.54)\end{array}$ \\
\hline Week 5 & $\begin{array}{c}6.50 \\
(7.86)\end{array}$ & $\begin{array}{c}1.99 \\
(7.89)\end{array}$ & $\begin{array}{r}-4.88 \\
(7.53)\end{array}$ & $\begin{array}{c}-3.05 \\
(6.83)\end{array}$ & $\begin{array}{r}-4.44 \\
(7.83)\end{array}$ & $\begin{array}{r}4.30 \\
(15.12)\end{array}$ \\
\hline $\mathrm{DV} \times$ week 2 & $\begin{array}{l}-5.84 \\
(11.76)\end{array}$ & $\begin{array}{l}-2.78 \\
(13.03)\end{array}$ & $\begin{array}{c}9.65 \\
(7.37)\end{array}$ & $\begin{array}{c}-31.70 \\
(48.65)\end{array}$ & $\begin{array}{c}-16.13 \\
(10.07)\end{array}$ & $\begin{array}{c}2.38 \\
(10.23)\end{array}$ \\
\hline $\mathrm{DV} \times$ week 3 & $\begin{array}{l}-5.46 \\
(10.41)\end{array}$ & $\begin{array}{l}-2.85 \\
(12.65)\end{array}$ & $\begin{array}{l}12.14 \\
(9.04)\end{array}$ & $\begin{array}{r}-16.44 \\
(49.34)\end{array}$ & $\begin{array}{c}0.96 \\
(11.59)\end{array}$ & $\begin{array}{c}-1.88 \\
(12.68)\end{array}$ \\
\hline DV $\times$ week 4 & $\begin{array}{r}-6.46 \\
(9.52)\end{array}$ & $\begin{array}{l}-8.67 \\
(13.21)\end{array}$ & $\begin{array}{l}19.46 \\
(8.92) * *\end{array}$ & $\begin{array}{c}-53.53 \\
(49.35)\end{array}$ & $\begin{array}{c}-3.29 \\
(9.90)\end{array}$ & $\begin{array}{r}-12.23 \\
(11.85)\end{array}$ \\
\hline $\mathrm{DV} \times$ week 5 & $\begin{array}{c}-23.49 \\
(12.51) *\end{array}$ & $\begin{array}{c}-17.15 \\
(14.99)\end{array}$ & $\begin{array}{c}8.95 \\
(16.46)\end{array}$ & $\begin{array}{c}-36.01 \\
(49.61)\end{array}$ & $\begin{array}{r}9.60 \\
(14.51)\end{array}$ & $\begin{array}{r}-10.12 \\
(19.57)\end{array}$ \\
\hline $\begin{array}{l}\text { Observations } \\
R^{2}\end{array}$ & $\begin{array}{l}728 \\
0.26\end{array}$ & $\begin{array}{c}743 \\
0.26\end{array}$ & $\begin{array}{l}745 \\
0.26\end{array}$ & $\begin{array}{l}745 \\
0.27\end{array}$ & $\begin{array}{l}745 \\
0.26\end{array}$ & $\begin{array}{l}710 \\
0.26\end{array}$ \\
\hline
\end{tabular}

Notes: Estimated on CSFII data restricted to households with individuals older than 62 obtaining Social Security income that is at least 80 percent of total income. Savings is defined as having cash, savings or checking accounts, stocks, bonds, mutual funds and certificates of deposit worth at least $\$ 5,000$. All regressions control for the variables listed in the footnote of Table 4. Standard errors are clustered by survey stratum in parentheses.

*** Significant at the 1 percent level.

** Significant at the 5 percent level.

* Significant at the 10 percent level.

Individuals with time preferences that display short-run impatience will want to procrastinate when deciding when to undertake costly activities aside from saving for future consumption (i.e., George A. Akerlof 1991; O’Donoghue and Matthew Rabin 1999; Stefano DellaVigna and Daniele M. Paserman 2005). We further document the importance of short-run impatience by estimating the shape of consumption profiles over the month separately for respondents with different observable indicators of present bias. Results are reported in Table 9 and are not, in general, very precisely estimated. Column 1 presents results for people who do and do not consume vitamin supplements. Column 2 distinguishes between smokers and nonsmokers, columns 3 and 4 distinguished between drinkers and nondrinkers and heavy drinkers and non-heavy drinkers, respectively, column 5 distinguishes by whether the respondent currently rents their home, and column 6 distinguishes by whether the respondent shops more than three times per month. Taking vitamins indicates smoother consumption and smoking indicates less smooth consumption, as expected. Individuals who shop more frequently have consumption profiles that drop while those who do not have smoother consumption. 
Table 10-Consumption Over the Pay Cycle by Savings Categories FOR DifFERENT INCOME ThreSholdS

\begin{tabular}{|c|c|c|c|c|c|c|c|c|c|}
\hline Benefits $>$ & $\begin{array}{c}0.9 \text { inc. } \\
\text { log energy } \\
\text { (1) }\end{array}$ & $\begin{array}{c}0.8 \text { inc. } \\
\text { log energy } \\
(2)\end{array}$ & $\begin{array}{c}0.7 \text { inc. } \\
\text { log energy } \\
\text { (3) }\end{array}$ & $\begin{array}{c}0.6 \text { inc. } \\
\text { log energy } \\
(4)\end{array}$ & $\begin{array}{c}0.5 \text { inc. } \\
\text { log energy } \\
(5)\end{array}$ & $\begin{array}{c}0.4 \text { inc. } \\
\text { log energy } \\
(6)\end{array}$ & $\begin{array}{c}0.3 \text { inc. } \\
\text { log energy } \\
(7)\end{array}$ & $\begin{array}{c}0.2 \text { inc. } \\
\text { log energy } \\
(8)\end{array}$ & $\begin{array}{c}0.1 \text { inc. } \\
\text { log energy } \\
\text { (9) }\end{array}$ \\
\hline No savings & $\begin{array}{c}4.88 \\
(7.17)\end{array}$ & $\begin{array}{c}2.76 \\
(7.03)\end{array}$ & $\begin{array}{c}1.01 \\
(5.83)\end{array}$ & $\begin{array}{c}-2.56 \\
(5.38)\end{array}$ & $\begin{array}{r}-3.40 \\
(4.87)\end{array}$ & $\begin{array}{c}-1.44 \\
(4.25)\end{array}$ & $\begin{array}{c}-2.60 \\
(4.03)\end{array}$ & $\begin{array}{r}-5.05 \\
(4.19)\end{array}$ & $\begin{array}{c}-6.71 \\
(4.14)\end{array}$ \\
\hline Week 2 & $\begin{array}{c}7.61 \\
(7.56)\end{array}$ & $\begin{array}{c}5.85 \\
(7.54)\end{array}$ & $\begin{array}{c}2.44 \\
(6.45)\end{array}$ & $\begin{array}{c}4.51 \\
(5.98)\end{array}$ & $\begin{array}{c}4.38 \\
(5.49)\end{array}$ & $\begin{array}{c}4.67 \\
(5.03)\end{array}$ & $\begin{array}{r}3.69 \\
(4.72)\end{array}$ & $\begin{array}{c}4.44 \\
(4.50)\end{array}$ & $\begin{array}{c}4.09 \\
(4.30)\end{array}$ \\
\hline Week 3 & $\begin{array}{c}9.56 \\
(9.05)\end{array}$ & $\begin{array}{c}8.04 \\
(7.86)\end{array}$ & $\begin{array}{c}8.73 \\
(6.65)\end{array}$ & $\begin{array}{c}7.13 \\
(5.97)\end{array}$ & $\begin{array}{r}6.89 \\
(5.11)\end{array}$ & $\begin{array}{c}8.82 \\
(4.35) * *\end{array}$ & $\begin{array}{c}9.68 \\
(4.08) * *\end{array}$ & $\begin{array}{l}8.24 \\
(4.22) *\end{array}$ & $\begin{array}{c}5.80 \\
(3.80)\end{array}$ \\
\hline Week 4 & $\begin{array}{l}10.31 \\
(7.40)\end{array}$ & $\begin{array}{c}6.10 \\
(7.12)\end{array}$ & $\begin{array}{c}8.44 \\
(5.93)\end{array}$ & $\begin{array}{c}9.13 \\
(5.22) *\end{array}$ & $\begin{array}{c}4.95 \\
(5.06)\end{array}$ & $\begin{array}{c}2.10 \\
(4.25)\end{array}$ & $\begin{array}{c}3.21 \\
(4.03)\end{array}$ & $\begin{array}{c}1.39 \\
(4.02)\end{array}$ & $\begin{array}{c}-0.58 \\
(3.90)\end{array}$ \\
\hline Week 5 & $\begin{array}{l}16.56 \\
(8.35)^{*}\end{array}$ & $\begin{array}{l}15.10 \\
(9.76)\end{array}$ & $\begin{array}{l}15.12 \\
(7.75)^{*}\end{array}$ & $\begin{array}{l}14.56 \\
(7.08) * *\end{array}$ & $\begin{array}{l}11.10 \\
(7.67)\end{array}$ & $\begin{array}{c}8.97 \\
(8.59)\end{array}$ & $\begin{array}{c}9.28 \\
(7.89)\end{array}$ & $\begin{array}{c}6.94 \\
(7.64)\end{array}$ & $\begin{array}{c}4.60 \\
(6.82)\end{array}$ \\
\hline NS $\times$ week 2 & $\begin{array}{r}-12.59 \\
(10.44)\end{array}$ & $\begin{array}{l}-9.43 \\
(10.21)\end{array}$ & $\begin{array}{c}-4.43 \\
(9.03)\end{array}$ & $\begin{array}{c}-7.28 \\
(8.53)\end{array}$ & $\begin{array}{c}-5.80 \\
(7.84)\end{array}$ & $\begin{array}{c}-9.81 \\
(7.50)\end{array}$ & $\begin{array}{c}-7.93 \\
(6.92)\end{array}$ & $\begin{array}{c}-7.18 \\
(6.66)\end{array}$ & $\begin{array}{c}-7.30 \\
(6.59)\end{array}$ \\
\hline $\mathrm{NS} \times$ week 3 & $\begin{array}{c}-13.19 \\
(10.79)\end{array}$ & $\begin{array}{c}-11.35 \\
(10.26)\end{array}$ & $\begin{array}{r}-11.52 \\
(9.07)\end{array}$ & $\begin{array}{r}-5.06 \\
(7.63)\end{array}$ & $\begin{array}{c}-4.49 \\
(6.53)\end{array}$ & $\begin{array}{c}-10.95 \\
(6.02) *\end{array}$ & $\begin{array}{c}-8.74 \\
(6.16)\end{array}$ & $\begin{array}{c}-5.00 \\
(6.28)\end{array}$ & $\begin{array}{c}-4.88 \\
(5.50)\end{array}$ \\
\hline $\mathrm{NS} \times$ week 4 & $\begin{array}{c}-15.38 \\
(10.02)\end{array}$ & $\begin{array}{c}-10.73 \\
(10.27)\end{array}$ & $\begin{array}{r}-12.08 \\
(9.36)\end{array}$ & $\begin{array}{c}-8.71 \\
(8.70)\end{array}$ & $\begin{array}{c}-5.92 \\
(8.34)\end{array}$ & $\begin{array}{c}-5.71 \\
(7.75)\end{array}$ & $\begin{array}{c}-7.52 \\
(7.29)\end{array}$ & $\begin{array}{r}-4.65 \\
(7.12)\end{array}$ & $\begin{array}{r}-2.07 \\
(6.69)\end{array}$ \\
\hline NS $\times$ week 5 & $\begin{array}{l}-38.27 \\
(12.60) * * *\end{array}$ & $\begin{array}{l}-35.20 \\
(14.35)^{* *}\end{array}$ & $\begin{array}{l}-29.87 \\
(14.06)^{* *}\end{array}$ & $\begin{array}{c}-23.68 \\
(12.11)^{*}\end{array}$ & $\begin{array}{c}-17.92 \\
(12.19)\end{array}$ & $\begin{array}{c}-15.31 \\
(12.48)\end{array}$ & $\begin{array}{r}-14.89 \\
(11.20)\end{array}$ & $\begin{array}{r}-13.57 \\
(10.92)\end{array}$ & $\begin{array}{r}-13.39 \\
(10.67)\end{array}$ \\
\hline Observations & 621 & 745 & 896 & 1,053 & 1,198 & 1,404 & 1,540 & 1,678 & 1,788 \\
\hline$R^{2}$ & 0.28 & 0.26 & 0.25 & 0.22 & 0.22 & 0.22 & 0.24 & 0.23 & 0.22 \\
\hline
\end{tabular}

Notes: Estimated on CSFII data restricted to households with individuals older than 62 obtaining Social Security income that is at least 80 percent of total income. Savings is defined as having cash, savings or checking accounts, stocks, bonds, mutual funds and certificates of deposit worth at least \$5,000. All regressions control for the variables listed in the footnote of Table 4 . Standard errors are clustered by survey stratum in parentheses.

*** Significant at the 1 percent level.

** Significant at the 5 percent level.

* Significant at the 10 percent level.

We expect more power in identifying the response of consumption to pay when Social Security payments constitute a large fraction of total income, and, for that reason, we have restricted our sample to Social Security recipients for whom benefits represent at least 80 percent of total income. Table 10 presents estimates of the unconstrained model with different income thresholds. Though smaller income thresholds increase the sample size, this is at the expense of introducing households into the sample that receive a lower fraction of their monthly income on the third of the month. The results are clear. Consumption of nonsavers in the final week of the Social Security benefit pay cycle is less than that of individuals with savings across income thresholds, and, as expected, the magnitude of the effect is smaller for lower income thresholds. The level of consumption also decreases over the month for nonsavers across income thresholds.

\section{Conclusions}

We provide evidence of quasi-hyperbolic discounting among the elderly that are reliant upon Social Security income. Individuals with low savings have consumption 
profiles that decline dramatically over the month, particularly in the final week of the pay period. We cannot prove that individuals with savings are not quasi-hyperbolic discounters, even though their food consumption profiles do not decline over the month. Savers may have the same time preferences as nonsavers, but their greater wealth implies that they will not have to rely exclusively on Social Security payments for their food budget. Further, individuals who have saved may have knowledge of, and access to, commitment devices such as illiquid investments that individuals without savings do not (Marianne Bertrand, Sendhil Mullainathan, and Eldar Shafir 2004).

Our results reinforce the view that government transfers ought to be made at higher frequencies 18 More frequent issuance of paychecks would limit the quasi-hyperbolic discounters ability to indulge in high current consumption at the expense of later consumption. With the small cost of issuing checks through direct deposit, allowing Social Security benefits recipients the ability to choose more frequent payments would result in a Pareto improvement upon the monthly schedule. This will be true even if the direct utility benefits are small given the small cost of sending money via direct deposit and the negative externalities of medical costs that may result from hyperbolic discounters not eating enough at the end of the month.

\section{Appendix: Derivation of Optimal Consumption Profile}

Here, we solve for the time $t$ consumer's consumption sequence. Assuming constant relative risk averse utility, the Euler equations can be written as

$$
\begin{aligned}
& t=0: c_{1}^{0}=(\beta \delta)^{1 / \rho} c_{0}^{0} \\
& t>0: c_{t}^{0}=\delta^{1 / \rho} c_{t-1}^{0}=\delta^{s / \rho} c_{t-s}^{0}=\beta^{1 / \rho} \delta^{t / \rho} c_{0}^{0} .
\end{aligned}
$$

Using this expression for initially planned time $t$ consumption in the budget constraint gives

$$
\begin{gathered}
y_{0}=c_{0}^{0}\left[1+(\beta \delta)^{1 / \rho} \frac{1-\delta^{T / \rho}}{1-\delta^{1 / \rho}}\right]=c_{0}^{0}\left[\frac{1+\left(\beta^{1 / \rho}-1\right) \delta^{1 / \rho}-\beta^{1 / \rho} \delta^{(T+1) / \rho}}{1-\delta 1 / \rho}\right] \\
\text { and } c_{0}^{0}=y_{0} \frac{1-\delta^{1 / \rho}}{1+\left(\beta^{1 / \rho}-1\right) \delta^{1 / \rho}-\beta^{1 / \rho} \delta^{(T+1) / \rho}} .
\end{gathered}
$$

Similarly, a time $t$ consumer will set $c_{0}^{t}=y_{t} \frac{1-\delta^{1 / \rho}}{1+\left(\beta^{1 / \rho}-1\right) \delta^{1 / \rho}-\beta^{1 / \rho} \delta(T+1-t) / \rho}$,

where $y_{t}=y_{0}-\sum_{s=0}^{t-1} c_{s}^{s}$. 
Setting $\delta=1$, the budget constraint simplifies to

$$
\sum_{t=0}^{T} c_{t}^{0}=\left(1+\beta^{1 / \rho} T\right) c_{0}^{0}=y_{0},
$$

and we get closed form solutions for $c_{t}^{t}$ :

$$
c_{t}^{t}=\frac{y_{0} \beta^{t / \rho} \prod_{s=0}^{t-1}(T-\mathrm{s})}{\prod_{s=0}^{t}\left[1+\beta^{1 / \rho}(T-s)\right]} .
$$

Taking logs gives

$$
\log c_{t}^{t}=\log y_{0}+\frac{t}{\rho} \log \beta+\log (T ! /(T-t) !)-\sum_{s=0}^{t} \log \left[1+\beta^{1 / \rho}(T-s)\right] .
$$

In case of no hyperbolic discounting and $\delta<1, \log (c)$ is a linear function of time since check arrival:

$$
\begin{gathered}
c_{t}=y_{0} \delta^{t / \rho} \frac{1-\delta}{1-\delta^{(T+1) / \rho}} \\
\log \left(c_{t}\right)=\log \left(y_{0}\right)+t / \rho \log (\delta)+\log \left(\frac{1-\delta}{1-\delta^{(T+1) / \rho}}\right) .
\end{gathered}
$$

\section{REFERENCES}

Aguiar, Mark, and Erik Hurst. 2005. “Consumption versus Expenditure.” Journal of Political Economy, 113(5): 919-48.

Ainslie, George. 1992. Picoeconomics. New York: Cambridge University Press.

Akerlof, George A. 1991. "Procrastination and Obedience." American Economic Review, 81(2): 1-19.

- Bertrand, Marianne, Sendhil Mullainathan, and Eldar Shafir. 2004. "A Behavioral-Economics View of Poverty." American Economic Review, 94(2): 419-23.

-Cleveland, William S. 1979. "Robust Locally Weighted Regression and Smoothing Scatterplots." Journal of the American Statistical Association, 74(368): 829-36.

-DellaVigna, Stefano, and M. Daniele Paserman. 2005. "Job Search and Impatience." Journal of Labor Economics, 23(3): 527-87.

Dobkin, Carlos, and Steven Puller. 2007. "The Effects of Government Transfers on Monthly Cycles in Drug Abuse, Hospitalization, and Mortality." Journal of Public Economics, 91(11-12): 2137-57.

-Frederick, Shane, George Loewenstein, and Ted O'Donoghue. 2002. "Time Discounting and Time Preference: A Critical Review." Journal of Economic Literature, 40(2): 351-401.

-Gul, Faruk, and Wolfgang Pesendorfer. 2001. "Temptation and Self-Control." Econometrica, 69(6): $1403-35$.

Hall, Robert E. 1978. "Stochastic Implications of the Life Cycle-Permanent Income Hypothesis: Theory and Evidence." The Journal of Political Economy, 86(6): 971-87.

Huffman, David, and Matias Barenstein. 2005. "A Monthly Struggle for Self-Control? Hyperbolic Discounting, Mental Accounting, and the Fall in Consumption Between Paydays." http://ftp.iza. org/dp1430_rev.pdf.

Hurst, Erik. 2003. "Grasshoppers, Ants, and Pre-Retirement Wealth: A Test of Permanent Income." National Bureau of Economic Research Working Paper 10098.

-Laibson, David. 1997. "Golden Eggs and Hyperbolic Discounting." Quarterly Journal of Economics, 112(2): 443-77.

-Laibson, David. 1998. "Life-Cycle Consumption and Hyperbolic Discount Functions." European Economic Review, 42(3): 861-71.

Laibson, David I., Andrea Repetto, and Jeremy Tobacman. 1998. "Self-Control and Saving for Retirement." Brookings Papers on Economic Activity, (1): 91-172. 
Laibson, David, Andrea Repetto, and Jeremy Tobacman. 2003. "A Debt Puzzle.” In Knowledge, Information, and Expectations in Modern Macroeconomics: In Honor of Edmund S. Phelps, ed. Philippe Aghion, Roman Frydman, Joseph Stiglitz, and Michael Woodford, 228-66. Princeton, NJ: Princeton University Press.

-Lawrance, Emily C. 1991. "Poverty and the Rate of Time Preference: Evidence from Panel Data." Journal of Political Economy, 99(1): 54-77.

O'Donoghue, Ted, and Matthew Rabin. 1999. "Doing it Now or Later," American Economic Review, 89(1): 103-24.

-Phelps, Edmund S., and Robert A. Pollak. 1968. "On Second-Best National Saving and Game-Equilibrium Growth.” The Review of Economic Studies, 35(2): 185-99.

Pollak, Robert A. 1968. "Consistent Planning." The Review of Economic Studies, 35(2): 201-08.

-Shapiro, Jesse M. 2005. "Is there a Daily Discount Rate? Evidence from the Food Stamp Nutrition Cycle." Journal of Public Economics, 89(2): 303-25.

-Skinner, Jonathan. 2007. "Are You Sure You're Saving Enough for Retirement?" Journal of Economic Perspectives, 21(3): 59-80.

-Stephens, Melvin, Jr. 2003. “'3rd of Tha Month': Do Social Security Recipients Smooth Consumption between Checks?" American Economic Review, 93(1): 406-22.

-Strotz, Robert H. 1955. "Myopia and Inconsistency in Dynamic Utility Maximization." The Review of Economic Studies, 23(3): 165-80.

Thaler, Richard H., and George Loewenstein. 1989. "Intertemporal Choice." Journal of Economic Perspectives, 3(4): 181-93.

United States Department of Agriculture. 1997. "Design and Operation: The Continuing Survey of Food Intakes by Individuals and the Diet and Health Knowledge Survey, 1994-96." NFS Report 96-1.

Weimer, Jon P. 1997. "Many Elderly at Nutritional Risk." USDA: Food Review, 20(1): 42-48.

-White, Michelle J. 2007. "Bankruptcy Reform and Credit Cards." Journal of Economic Perspectives, 21(4): 175-99. 